\title{
Mental health care for parents of babies with congenital heart disease during intensive care unit admission: Systematic review and statement of best practice
}

\author{
Nadine A. Kasparian, ${ }^{1,2,3}$ Janice M. Kan, ${ }^{3,4}$ Erica Sood,,${ }^{5,6}$ Jo Wray, ${ }^{7,8,9}$ \\ Harold A. Pincus ${ }^{10,11} \&$ Jane W. Newburger ${ }^{1,2}$
}

\footnotetext{
${ }^{1}$ Department of Pediatrics, Harvard Medical School, Boston, Massachusetts, USA.

${ }^{2}$ Department of Cardiology, Boston Children's Hospital, Boston, Massachusetts, USA.

${ }^{3}$ Discipline of Paediatrics, School of Women's and Children's Health, UNSW Medicine, The University of New South Wales (UNSW Sydney), Sydney, Australia.

${ }^{4}$ Heart Centre for Children, The Sydney Children's Hospitals Network Cardiac Service, Sydney, Australia.

${ }^{5}$ Nemours Cardiac Center, Alfred I. duPont Hospital for Children, Wilmington, Delaware, USA.

${ }^{6}$ Department of Pediatrics, Sidney Kimmel Medical College, Thomas Jefferson University, Philadelphia, Pennsylvania, USA.

${ }^{7}$ Heart and Lung Directorate, Great Ormond Street Hospital for Children NHS Foundation Trust, London, United Kingdom.

${ }^{8}$ Institute of Cardiovascular Science, UCL, London, United Kingdom.

${ }^{9}$ National Institute of Health Research, Great Ormond Street Hospital Biomedical Research Centre, London, United Kingdom.

${ }^{10}$ Department of Psychiatry and Irving Institute for Clinical and Translational Research, Columbia University, New York, USA.

${ }^{11}$ New York State Psychiatric Institute, New York, USA.
}

Please send correspondence to: Nadine Kasparian, Department of Cardiology, Boston Children's Hospital, 300 Longwood Avenue, Boston, MA 02115, USA. Telephone: +1-617-838-1202, Email: nadine.kasparian@childrens.harvard.edu, Twitter: @NKasparian 
Acknowledgements: This work was supported by Project Grants from the National Health and Medical Research Council (NHMRC) of Australia (Kasparian APP1081001), HeartKids Australia, and Seed Funding from the UNSW Neuroscience, Mental Health \& Addictions Theme and SPHERE Mindgardens Clinical Academic Group. N Kasparian is the recipient of a 2018-2019 Harkness Fellowship in Health Care Policy and Practice from the Commonwealth Fund in New York, and a National Heart Foundation of Australia Future Leader Fellowship (101229). E Sood is the recipient of a PEDSnet Scholars K12 grant from the Agency for Healthcare Research and Quality. 


\section{ABSTRACT}

Introduction: Congenital heart disease (CHD) is one of the most common causes of infant admission to pediatric intensive care and is associated with profound psychological stress for mothers, fathers and their infants. Intensive care unit admission represents an opportunity to offer evidence-based strategies to prevent or minimize severe psychological distress and promote secure bonding and attachment, alongside high-quality infant medical care.

Objectives: We aimed to identify, synthesize and critically appraise published evidence on the efficacy and cost-effectiveness of mental health interventions delivered in neonatal, pediatric or cardiac intensive care units for parents of infants with CHD. A secondary goal was to develop recommendations for advancing health policy, practice and research in the field.

Methods: In accordance with a prospectively registered protocol (CRD42019114507), six electronic databases were systematically searched for studies reporting results of a controlled trial of a mental health intervention for parents of infants aged 0-12 months with a congenital anomaly requiring intensive care unit admission. To maximize generalizability of results, trials involving infants with any type of structural congenital anomaly requiring surgery were included. Outcomes included intervention type, process, efficacy, and cost-effectiveness.

Results: Across all forms of congenital anomaly, only five trials met inclusion criteria (four in CHD, one in gastrointestinal malformation). All interventions engaged parents face-to-face, but each had a distinct therapeutic approach (parent-infant interaction and bonding, early pediatric palliative care, psychoeducation, parenting skills training, and family-centered nursing). Four of the five trials demonstrated efficacy in reducing maternal anxiety, although the quality of evidence was low. Positive results were also found for maternal coping, mother-infant attachment, parenting confidence and satisfaction with clinical care, as well as infant mental (but not psychomotor) development at 6 months. Mixed results were found for maternal depression and infant feeding. No evidence of efficacy was found for improving parent, infant or family quality of life, physical health or length of infant hospital stay, and there were no data on costeffectiveness.

Conclusions: Stronger evidence for the efficacy of mental health interventions to buffer the effects of intensive care unit admission for parents of infants with CHD is urgently needed. Robust, high-quality 
trials are lacking, despite the established need and demand, and health policies prioritizing parent mental health care in the context of early childhood adversity are needed.

KEYWORDS: Congenital heart disease; congenital anomaly; neonatal intensive care unit; pediatric intensive care unit; cardiac intensive care unit; mental health; behavioral health; anxiety; psychological intervention; systematic review; guidelines. 


\section{INTRODUCTION}

Worldwide, more than 1.35 million babies are born with some form of heart anomaly each year. ${ }^{1}$

Congenital heart disease (CHD) is one of the most common causes of infant admission to pediatric intensive care, ${ }^{2}$ a leading cause of infant death, ${ }^{3}$ and one of the leading causes of disease-related disability in children under age five years. ${ }^{4,5}$ Infants with complex forms of CHD typically require cardiac surgery in the first days, weeks or months following birth, often returning to the intensive care unit with a mediastinal incision, artificial airway with mechanical ventilation, and peripheral, central or intracardiac catheters. Postoperatively, these infants are at risk for hemodynamic instability, persistent hypoxemia, malignant arrhythmias, multiorgan dysfunction, seizures, thrombosis, and infection. ${ }^{6}$ While fiscal estimates vary by country, in the United States hospital costs for neonates and children with CHD represent approximately $23 \%$ of global hospital costs while accounting for only $4.4 \%$ of discharges. ${ }^{7}$ Analysis of data from the 2009-2010 U.S. National Survey of Children with Special Health Care Needs found 89\% of families of children with CHD and special health care needs reported at least one financial burden, including out-ofpocket healthcare expenses $>\$ 1,000$ (30\% of families), financial problems due to their child's condition (35\%), reduced or terminated employment (43\%), and increased caregiving hours $(23 \%) .{ }^{8}$ Moreover, families who reported at least one financial burden were almost three times more likely to use mental health services than those without financial burden. ${ }^{8}$

Neurobehaviorally, infants with complex CHD are often hypersensitive to stimuli ${ }^{9}, 10$ and experience difficulties with settling, soothing and feeding. ${ }^{10-12}$ Studies suggest that brain maturation may be delayed in infants with certain forms of complex $\mathrm{CHD},{ }^{13,14}$ which may contribute to atypical autonomic, state and motor organization, feeding difficulties, and other challenges in regulatory functioning. ${ }^{15}$ A substantial proportion (up to 50\%) of infants with complex CHD exhibit neurodevelopmental impairments, including developmental delays, learning deficits, and difficulties with emotional and behavioral regulation. ${ }^{16-21} \mathrm{~A}$ range of factors may contribute to neurodevelopmental vulnerability in this population, including disease complexity and comorbidity, prematurity, history of mechanical support, cardiopulmonary resuscitation or peri-operative seizures, stroke, and greater length of perioperative intensive care unit and total hospital 
stay. ${ }^{18,22,23}$ In addition, our understanding of the genetic and epigenetic contributions to neurodevelopmental vulnerability in infants with CHD is rapidly evolving. ${ }^{17,24}$

Recognition of the role of ecological factors is also growing, particularly in terms of the potential lifelong health consequences of frequent and cumulative exposure to early childhood adversity and toxic stress..$^{25,26}$ For critically-ill infants within the neonatal (NICU), pediatric (PICU) or cardiac intensive care unit (CICU), stressors can originate from the physical environment (e.g., bright lights, loud sounds, noxious smells), ${ }^{27,28}$ clinical environment (e.g., painful and invasive but life-sustaining procedures, neurotoxic medications), ${ }^{29,30}$ and psychosocial environment (Figure 1). ${ }^{31-33}$ While excellent reviews have been published on the role of physical and clinical environmental factors, ${ }^{\text {e.g. } 26,34}$ it is the psychosocial environment that is of primary concern in the present review.

[Insert Figure 1 about here]

For parents of infants with complex CHD, the highly technological intensive care unit environment is foreign and frightening. Extensive research over several decades has documented the high levels of stress and distress experienced by mothers and fathers as a result of their baby's cardiac diagnosis and hospitalization, particularly in the perioperative phase. ${ }^{35-37}$ With marked improvements in survival after cardiac surgery, ${ }^{38}$ the needs of these medically-fragile infants have become increasingly complex. A substantial proportion of babies with complex CHD are now diagnosed in utero, most at approximately 20 weeks gestation, and this is often a time of intense sadness, fear, anger and grief for expectant parents emotions that tend to endure throughout the remainder of the pregnancy and well beyond infant hospital discharge. ${ }^{39-44}$ Parents commonly describe fears their infant will die, ${ }^{40}$ as well as distress associated with the need to make difficult, time-sensitive treatment decisions, bearing witness to painful procedures or traumatic events, periods of separation from their infant, alterations in parental role, and uncertainty about the future and their child's prognosis. ${ }^{45-50}$ For many infants with complex CHD, the process of postoperative recovery is non-linear, requiring multidisciplinary care to manage comorbid conditions and complications which can further exacerbate parental distress. ${ }^{51,52}$ 
Threats to the health of the fetus or infant have long been recognized as an important risk factor for parental psychiatric disturbance in the perinatal period. In a recent systematic review of parental mental health in the context of complex $\mathrm{CHD}$ ( $N=30$ studies), ${ }^{35}$ up to $30 \%$ of parents were found to have symptoms consistent with a diagnosis of post-traumatic stress disorder, with over $80 \%$ presenting with clinically-significant symptoms of trauma at the time of infant hospital discharge. Across various time-points from surgical intervention, 25-50\% of parents reported clinically-elevated symptoms of depression or anxiety, and 30$80 \%$ reported experiencing severe psychological distress. These rates exceed national norms: $;^{53,54}$ yet, the severity and consequences of these symptoms are often markedly underestimated by healthcare providers. ${ }^{55}$ In addition to infant medical factors, parental vulnerability to perinatal anxiety and depression may be heightened in the presence of a personal or family history of mental illness, early childhood adversity (physical, sexual or emotional abuse or neglect, trauma or domestic violence), stressful life events (e.g., recent bereavement, unresolved grief), low partner support, limited social support networks, and a tendency to idealise parenthood. ${ }^{56,57}$ Parents with higher distress report poorer physical health, ${ }^{42}$ greater parenting burden ${ }^{58}$ higher health service use,${ }^{59}$ more suicidal ideation,,${ }^{54}$ and poorer parent and child quality of life $\mathrm{s}^{5,60}$ compared with parents of sick children with lower distress. Experiencing anxiety and depressive symptoms can also make it more difficult for parents to develop a secure bond with medically-fragile infant. Numerous independent prospective studies of children free of chronic illness have demonstrated a link between maternal anxiety in the perinatal period and greater child neurodevelopmental, behavioral and emotional difficulties from birth to adulthood. ${ }^{61}$ Similar findings are beginning to emerge for children with complex $\mathrm{CHD},{ }^{62,63}$ demonstrating the importance of parental mental health to child development and wellbeing.

Infants' stay in the intensive care unit represents an opportunity not only for high-quality infant medical care, but also to offer parents evidence-based strategies to prevent or minimize severe psychological distress, and promote secure bonding and attuned parenting. While studies examining the efficacy of psychological interventions for parents of premature infants in the NICU offer important insights, ${ }^{64,65}$ we and others ${ }^{34,66}$ believe there are fundamental medical, neurological, behavioral and parental differences in the cardiac setting that warrant distinct investigation and unique models of mental health care. Thus, the primary aim of this review was to systematically identify, synthesize and critically appraise published 
evidence on the efficacy and cost-effectiveness of controlled psychological (or psychologically-informed) interventions delivered in the neonatal, pediatric or cardiac intensive care unit setting for parents of infants with CHD. A secondary goal was to use this evidence to inform the development of a statement of best practice for the mental health care of parents of infants with CHD requiring intensive care unit admission, including a series of recommendations for advancing clinical practice, health policy and research in the field.

\section{METHODS}

\section{Data search strategy and sources}

The review protocol was prospectively registered with PROSPERO (CRD42019114507), and the Preferred Reporting Items for Systematic reviews and Meta-Analyses (PRISMA) guidelines were used to identify, screen and extract data from published articles. ${ }^{67}$ A systematic search was carried out in October 2018 using six electronic databases (Medline, Embase, PsycINFO, the Cumulative Index to Nursing and Allied Health Literature, EMcare, Scopus). The search strategy was developed in Medline and adapted for use in each database. A string of key terms was combined for each search, including: congenital anomaly, birth defect, congenital heart disease, neonatal intensive care, pediatric intensive care, psychological intervention, psycho-education, mental health service, parents and caregivers (comprehensive search strategy available on request). To maximize the number of articles returned, we did not apply date range restrictions. Ancestry methods, citation chaining and prolific author searching in Scopus were used to identify additional articles. Auto-alerts were created using the same unique search algorithm for each database, with findings incorporated into the review until December 2018.

\section{Study selection criteria}

Studies were eligible for review if they were controlled trials delivering a psychological intervention for parents of infants (aged 0-12 months) with a congenital anomaly. To maximize the potential generalizability of findings, the search included all types of structural congenital anomaly. Studies were included only if the intervention was delivered in the context of infant NICU, PICU or CICU admission. For the purposes of this review, 'psychological intervention' was defined as any intervention based on: (a) 
specific psychological principles, skills or techniques, (b) a psychological theory, or (c) input from a mental health professional and was delivered in isolation or in conjunction with other medical, practical or educational components. ${ }^{68}$ Examples include psycho-education, cognitive-behavioral therapy, mindfulnessbased stress reduction, and psychoanalytic psychotherapy. Control arms could include any active or attentional placebo, waitlist control, or standard care conditions.

The Cochrane Handbook for Systematic Reviews recommends pre-specifying primary and secondary outcomes in published protocols to safeguard against biases in outcome reporting. ${ }^{69,70}$ Given the high prevalence of anxiety reported by parents of infants with life-threatening medical illness, ${ }^{\text {e.g. } 35}$ anxiety was chosen as the primary outcome, as defined by: (a) scores on a validated self-report questionnaire (e.g., State-Trait Anxiety Inventory), or (b) diagnostic status based on a structured or semi-structured clinical interview. Secondary outcomes included: depressive symptoms, psychological stress or distress, healthrelated quality of life, adjustment and coping responses, attachment-related outcomes (e.g., parent-infant bonding), family-related outcomes (e.g., parenting stress, family functioning), parent or infant physical health, infant developmental outcomes (e.g., neurodevelopment, feeding), and parent satisfaction with clinical care. Data on intervention acceptability, feasibility, adverse events and cost-effectiveness were also collected, wherever available. Studies with mixed samples where outcomes were not reported separately or where less than $50 \%$ of the sample comprised infants with a congenital anomaly were excluded, as were case studies, non-peer-reviewed studies (e.g., dissertations), and those using historical control groups.

Titles were screened by one reviewer (J.K.), and two reviewers (J.K., N.K.) independently assessed abstracts and full-texts to determine eligibility. Coding differences were resolved through consensus or consultation with a third reviewer. While review articles were excluded from analysis, these were collected and screened to ensure concept originality. No published reviews of a similar nature to the present study were identified.

\section{Data extraction}

Data extraction was initially carried out by one reviewer (J.K.) using a standardized data collection form and checked for accuracy by a second reviewer (N.K.). Extracted data included: trial characteristics (e.g., country, study design, recruitment setting), sample characteristics (e.g., sample size, demographics, clinical 
characteristics), intervention methods (e.g., type, delivery mechanism, content, duration), and results (e.g., change in psychological outcomes from baseline to follow-up), as relevant to the review.

\section{Risk of bias assessment}

Risk of bias was independently assessed by two reviewers (E.S., J.K.). For randomized controlled trials, the Cochrane Collaboration Tool for Assessing Risk of Bias was used to rate sources of bias across six domains (selection, performance, detection, attrition, reporting, other bias), with risk categorized as 'high', 'unclear' or 'low' ${ }^{71}$ For non-randomized trials, the Cochrane Risk of Bias in Non-Randomized Studies of Interventions (ROBINS-I) tool was used to assess risk of bias across seven domains (confounding, selection bias, intervention classification, deviation from intended interventions, missing data, outcome measurement, selective reporting), with risk categorized as 'low', 'moderate', 'serious', 'critical' or 'unclear'. ${ }^{72}$ Implementation integrity was coded based on intervention manualization and fidelity checks. Any conflicts of opinion were resolved through consensus or consultation with a third reviewer (N.K.).

\section{Assessment of quality of evidence}

The Grading of Recommendations Assessment, Development and Evaluation (GRADE) rating system was used to assess quality of evidence where at least three studies measured comparable outcomes. ${ }^{73}$ Quality of evidence was rated across five domains: (1) study design and implementation limitations, (2) unexplained heterogeneity or inconsistency of results, (3) indirectness of evidence, (4) imprecision of effect estimates, and (5) publication bias, and categorised as 'very low', 'low', 'moderate' or 'high'.

\section{Data synthesis and analysis}

Narrative synthesis was the primary reporting method. Statistical synthesis using meta-analysis was attempted but considered uninformative, given the small number of trials and disparate interventions, comparators, outcome measures, and study designs; however, effect sizes were provided as an estimate of efficacy. Effect sizes (Hedge's g, to correct for bias associated with small samples) were calculated for each outcome based on standardized mean differences between intervention and control groups from baseline (pre-intervention) to first post-intervention assessment. ${ }^{74}$ Means, standard deviations (SD), and 
intention-to-treat data were used where possible to increase precision of estimates.

\section{RESULTS}

\section{Study selection}

Database searching yielded 278 articles, 11 articles were identified via additional sources, and 217 unique articles remained after removing duplicates (Figure 2). After title and abstract screening, 29 full-texts were assessed and reference chaining was performed. In total, five articles reporting on five unique trials met inclusion criteria.

[Insert Figure 2 about here]

\section{Study, intervention and sample characteristics}

Overall, the studies reported on data from 339 participants, with sample sizes ranging from 38 to 108 participants (Table 1). All studies reported on data for mothers $(n=311)$ and while two studies recruited both mothers and fathers, ${ }^{75,76}$ only one trial reported on outcome data for fathers $(n=28) .{ }^{76}$ Publication dates ranged from 2010 to 2019 , two studies reported trial registration, ${ }^{77,78}$ and no studies cited a published protocol. Four trials included infants with congenital heart disease (with one trial also including infants with hypoxic-ischemic encephalopathy or prematurity ${ }^{76}$ ). The remaining trial included infants with congenital gastrointestinal malformations. ${ }^{78}$ Two trials used a randomized design, ${ }^{77,78}$ three were nonrandomized trials, and all used a two-group (intervention versus control) design. Control conditions included usual care only; no trials used an attentional or waitlist control. All trials included two assessment points (one pre-intervention, one post-intervention), with follow-up periods ranging from 12 hours prior to ICU discharge ${ }^{79}$ to 6 -months postpartum. ${ }^{75}$

[Insert Table 1 about here]

While all interventions had been developed for parents of infants requiring intensive care unit admission, the interventions varied considerably in therapeutic orientation, content, format, process, duration, dose and 
interventionist (Table 2). All interventions commenced within two weeks of infant intensive care unit admission (most within four days of admission) and were delivered face-to-face, often by the infant's bedside. Three interventions ${ }^{75,76,78}$ were delivered by a psychologist (one in collaboration with a cardiac nurse specialist, ${ }^{75}$ one with a member of the research team ${ }^{78}$ ), one was delivered by a pediatric palliative care team, ${ }^{77}$ and one by PICU nursing staff. ${ }^{79} \mathrm{~A}$ conceptual model had been used to guide intervention development in all cases; however, most studies did not provide detailed information on the model or therapeutic orientation. All interventions except one aimed to reduce parental stress or anxiety. Additional intervention targets included parental emotional distress, depressive symptoms, quality of life, adaptive coping, mother-infant interaction or attachment, infant feeding and neurodevelopment, family functioning, communication and satisfaction with clinical care. Provision of medical information tailored to the infant's diagnosis was common across all interventions. Other common intervention components included collaborative goal-setting and shared decision-making, emotional expression, and parenting skills training. Intervention duration and 'dose' varied substantially both within and across trials, and only one trial reported on the average time participants spent engaged with the intervention. ${ }^{75}$

\section{[Insert Table 2 about here]}

\section{Risk of bias and GRADE assessment}

Risk of bias across all studies was high or serious in at least three domains. For the RCTs, ${ }^{77,78}$ risk of selection, performance, detection, attrition, and reporting bias was high or unclear in at least one or both trials (Table 3). For non-randomized trials, ${ }^{75,76,79}$ confounding, participant selection, outcome measurement, and selective reporting posed a moderate or serious risk of bias across all trials (Table 4). It was unclear whether trials deviated from intended interventions. Three of the five trials were not registered, ${ }^{75,76,79}$ and none referenced protocols. Only one trial described treatment or control manualization or fidelity checking. ${ }^{75}$ Small sample sizes were common and no study reported on missing data handling. Due to measure heterogeneity, GRADE ratings could only be calculated for anxiety. Overall, quality of evidence was 'very low' (Table 5). 


\section{Efficacy}

Anxiety (primary outcome): Four trials examined the effects of psychological intervention on parental anxiety, with anxiety measured using the validated State-Trait Anxiety Inventory in all but one ${ }^{76}$ of the studies. All reported a significant reduction in parental anxiety following intervention (Table 6), with two of the four trials ${ }^{75,79}$ indicating medium to large effect sizes (Table 7).

[Insert Tables 6 and 7 about here]

Depression: Two of the five trials measured the effects of intervention on depressive symptoms. While depression was assessed using the Beck Depression Inventory in both trials, mixed results were yielded. No significant difference in change in depressive scores was found between intervention and control groups following early pediatric palliative care for parents of infants with single ventricle CHD ${ }^{77}$ After individualized psychological support during NICU admission, Cano-Giménez et al. found 50\% of mothers and $20 \%$ of fathers in the intervention group reported depressive symptoms in the 'clinical' range, compared with $100 \%$ of parents in the control group. In addition, $37.5 \%$ of mothers and $24 \%$ of fathers in the intervention group reported scores consistent with 'probable depression' on the Edinburgh Postnatal Depression Scale at the time of NICU discharge, compared with $100 \%$ of mothers and $89.7 \%$ of fathers in control group. Mean depression scores were not reported in this study.

Psychological distress: While three ${ }^{75-77}$ of the five trials assessed parental psychological distress or worry, only two trials examined potential changes in distress post-intervention. Six months after a 6-session intervention facilitated by a pediatric clinical psychologist and cardiac nurse specialist during infant hospital admission, mothers reported significantly lower worry compared with those who had not received the intervention (small to medium effect size).${ }^{75}$ Early pediatric palliative care did not yield a significant difference in change in overall maternal distress between intervention and control groups. ${ }^{77}$

Coping and adjustment: Two trials assessed intervention effects on maternal coping. One trial of a parentinfant intervention found moderate improvement in positive reinterpretation and growth (medium effect 
size), but not in active coping, planning, or behavioral disengagement. ${ }^{75}$ Similarly, mothers who received early pediatric palliative care reported greater positive reframing (but not greater overall 'adaptive' coping) compared with those who received standard care (medium effect size).$^{77}$

Mother-infant attachment and parenting confidence: Only one trial assessed the effects of psychological intervention on mother-infant attachment. In Iran, Jabraili et al. found that a support program focused on providing psycho-education and enhancing mother-infant attachment led to a greater increase in selfreported mother-infant attachment in the intervention group compared with the control group. ${ }^{78}$ One trial of a mother-nurse partnership program in South Korea examined the effect of intervention on perceived parenting confidence (or self-efficacy) using a self-report questionnaire. ${ }^{79}$ Uhm et al. found that mothers in the intervention group reported significantly greater improvement in parenting confidence compared with mothers who received usual care (large effect size).${ }^{79}$ When the clinical cut-off was applied, no mothers in the intervention group, compared with 7 (of 37) mothers in the control group, scored within the clinical range indicative of a need for further assessment and support.

Infant feeding: Two of the five trials examined the potential consequences of mental health intervention for infant feeding, with mixed results. While post-intervention improvements in time taken for infants to reach full oral feeding ${ }^{79}$ or to complete feeds ${ }^{75}$ were not found, one trial of a parent-infant psychotherapeutic intervention did find differences in the proportion of mothers who were breastfeeding their infants at 6 months (19\% in the intervention group versus $0 \%$ in the control group) ${ }^{75}$ Also, a significantly lower proportion of mothers in this intervention group reported difficulty introducing solids to their infant's diet compared with mothers who received usual care $(16 \%$ versus $44 \%) .^{75}$

Infant neurodevelopment: Only one trial examined the effects of psychological intervention for infant neurodevelopment. ${ }^{75}$ Using the well-validated Bayley Scales of Infant Development, infants in the psychotherapeutic intervention group had significantly higher (better) mental development scores at 6 months of age ( $M=98.4, S D=11.1)$ compared with infants in the control group ( $M=86.7, S D=17.7)$, irrespective of syndromal status (medium to large effect size). No difference in infant psychomotor development scores was found, with the mean for both intervention $(M=69.3, S D=17.1)$ and control 
( $M=71.7, S D=18.1)$ groups falling 1 to 2 standard deviations below the normative mean, indicating clinically-significant levels of delay in psychomotor functioning.

Family functioning: One trial (of early pediatric palliative care) examined the effects of intervention on family relationships. Hancock et al. assessed change in mothers' perceptions of family functioning using the Pediatric Quality of Life Inventory and found a 5-point increase in family relationships scores for the intervention group compared with a 2.6-point reduction for the control group; this result was not statistically significant (small to medium effect size). ${ }^{77}$

Health-related quality of life: One trial tested the impact of intervention on maternal health-related quality of life and found no difference between intervention and control group scores at 30 days postpartum. ${ }^{77}$

Physical health: None of the identified trials examined the effects of mental health intervention on maternal, paternal or infant physical health outcomes or biomarkers of stress. One trial did, however, examine length of PICU stay and found a mother-nurse partnership program had no effect on this outcome. $^{79}$

Communication and satisfaction with clinical care: Working with mothers of neonates with single ventricle CHD, Hancock et al. assessed the influence of early pediatric palliative care on perceived communication about child health (broadly and with doctors and nursing staff) and found that while mothers in the intervention group reported an 11.3-point increase in communication scores compared with a 1-point increase in the control group, this result was not statistically significant (medium effect size) ${ }^{77}$ Another trial examined the effects of intervention on maternal satisfaction with clinical care and found a mothernurse partnership program improved satisfaction with all assessed aspects of PICU care (information, care and cure, organization, parental participation, and professional attitude; large effect size). ${ }^{79}$ Mothers in the intervention group also perceived all aspects of the parent-nurse partnership more positively than mothers who received usual care, including higher scores for perceived professional knowledge, sensitivity, collaboration, communication, shared information, reciprocity, and cautiousness. ${ }^{79}$ 


\section{Intervention acceptability and safety}

Only three of the five trials reported response (range: 53-96\%) and attrition (range: 0-11\% intervention, 0 $34 \%$ control groups) rates. ${ }^{75,77}$ In addition, one trial reported the attrition rate for fathers $(60 \%$ intervention, $38 \%$ control) but not mothers. ${ }^{76}$ Adverse effects were not reported in any of the trials.

\section{Cost-effectiveness}

No study reported health economic data.

\section{DISCUSSION}

To inform best practice principles for the mental health care of parents and their infants with CHD during intensive care unit admission, we carried out a systematic review of all relevant, available evidence derived from controlled trials. This process revealed an extremely limited evidence base. Only five trials (2 randomized, ${ }^{77,78} 3$ non-randomized ${ }^{75,76,79}$ ) examining the efficacy of psychologically-informed interventions were identified, and the results derived from these trials must be interpreted with caution, due to indications of high or serious risk of bias. Offering opportunities for engagement with high-quality psychotherapeutic interventions that are integrated within, and tailored to address, the unique demands of the intensive care unit environment is hypothesized to prevent or minimize severe psychological distress in parents of medically-fragile infants. ${ }^{80-83}$ There is also the potential that such interventions will bolster infant-parent bonding and attachment, and provide some buffering from the effects of early medical adversity. This review provides partial support for these hypotheses, and signals a clear need for replication and prioritization for filling evidence gaps to inform practice.

Four of the five identified interventions, each with a different therapeutic approach, demonstrated efficacy in reducing maternal symptoms of anxiety. This contrasts with the findings of a recent meta-analysis, which reported limited efficacy of psychological interventions in reducing maternal anxiety in the NICU, where the primary reason for admission was prematurity or low birth weight. ${ }^{64}$ In our review, however, when the quality of evidence relating to anxiety was assessed using the widely-endorsed GRADE rating system, ${ }^{73}$ it was found to be 'very low', limiting our capacity to make firm recommendations based on the 
data. Surprisingly, only two trials assessed depression; one showing a positive effect of psychological intervention on depressive symptoms ${ }^{76}$ and the other showing no effect. ${ }^{77}$ Greater use of validated measures of depression in future studies is strongly recommended, given meta-analytic data demonstrating significant intervention effects on depressive symptoms in mothers of premature infants in the NICU. ${ }^{64}$ Encouraging, if not preliminary, results were also found in terms of positive intervention effects on maternal coping, mother-infant attachment, parenting confidence, family functioning, communication, and satisfaction with clinical care; however, due to the very limited number of trials examining intervention effects on these outcomes, the quality of evidence could not be determined. Moreover, no evidence of efficacy was found for improved parental or family quality of life or infant length of intensive care unit stay, and there were no data on cost-effectiveness. Strikingly, one trial of a parent-infant interaction intervention was able to demonstrate benefits for infant mental (but not psychomotor) development at 6 months. This finding is important in the context of complex CHD, given the high risk of neurodevelopmental deficits in this population, ${ }^{14,18}$ and provides a platform for future research investigating the potential mechanisms of, and potent vehicles for, sustained effect.

\section{Limitations of captured studies and the current review}

The findings of this review demonstrate that psychological interventions for parents of infants with complex CHD (or any congenital anomaly) are in the early stages of research and that existing studies are predominantly pilot in nature, rather than large-scale, randomized controlled trials of intervention efficacy. Methodological limitations common across the captured studies included small sample sizes, single center recruitment, lack of blinding and active control conditions, and reliance on self-administered, symptombased measures of mental health to assess efficacy, without reference to clinical cut-offs or diagnostic assessments (e.g., structured clinical interviews) to provide indications of clinically-meaningful psychological change. Some of these issues, amongst others, resulted in all studies being assessed to have high risk of bias. Substantial variation in intervention delivery within trials, and variation in the outcomes assessed across trials, precluded examination of potential mediation and moderation effects. Moreover, none of the reviewed studies used intention-to-treat analyses, such that potential differential effects for participants retained versus lost to follow-up were unclear. In addition, lack of trial registration or a priori 
protocol publication inhibited transparency and is likely to impede future replication and implementation of efficacious interventions in clinical practice.

Across this body of work, fathers were noticeably absent, with only one of the five captured trials reporting on paternal outcome data. ${ }^{76}$ This represents an important knowledge gap, particularly given the prevalence of paternal psychological distress gleaned from recent systematic reviews in both NICU ${ }^{84}$ and $\mathrm{CHD}^{35}$ settings. In the study by Cano-Giménez et al., which did include fathers, an overall attrition rate of $48 \%$ was reported for fathers who initially enrolled in the trial, and attrition was higher for fathers in the intervention (60\%) compared with control (38\%) arm. ${ }^{76}$ Burgeoning research into improving men's engagement with psychological treatments makes claim for a 'masculinities model', ${ }^{85}$ which actively takes into account the role of gender norms in help-seeking behavior. Studies show that tailoring and targeting mental health interventions may increase men's uptake and engagement, as well as the efficacy of treatment. ${ }^{86}$ On a practical level, clinician use of specific process micro-skills (e.g., self-disclosure, normalizing), language adaption (e.g., male-oriented metaphors), and treatment styles (e.g., collaborative, transparent, action-oriented, goal-focused) have been found to bolster men's engagement with psychotherapy, ${ }^{87}$ though these strategies have yet to be tested in fathers of infants with critical illness.

The present review is also not without limitations. The small number of eligible studies reduced our ability to detect treatment effects. This, and the heterogeneity of methodologies used across the captured studies, made it difficult to pool results and precluded meta-analysis. The reviewed trials also did not provide sufficient information to comment on potential effects associated with race, ethnicity, or cultural or socioeconomic diversity. Greater representation of racial, ethnic and socioeconomic diversity is particularly important, given the influence of these factors on physical and mental health service use..$^{8,88}$

\section{New frontiers: Recommendations for advancing clinical practice, health policy and research}

The U.S. Academy of Sciences framework for establishing evidence-based standards for psychosocial interventions provides a roadmap for advancing health policy and practice in our field (Figure 3). ${ }^{89}$ This framework identifies key, iterative steps involved in successfully bringing an evidence-based psychosocial intervention into clinical practice. Highlighted is the need to: (1) support research to strengthen evidence on 
the efficacy and effectiveness of psychosocial interventions; (2) identify the key elements that drive intervention effectiveness; (3) conduct systematic reviews to inform clinical guidelines incorporating these key elements; (4) develop quality measures to assess the structure, process, outcomes and cost of interventions; and (5) establish methods for successfully implementing and sustaining these interventions in routine practice, including health provider training. Diverse patient and family perspectives (including the perspectives of 'harder to reach' groups, such as fathers and families from diverse cultural and socioeconomic backgrounds) heavily inform all framework components.

\section{[Insert Figure 3 about here]}

There is no question that rigorous testing of mental health interventions for parents of infants with CHD is needed. A range of therapeutic approaches (e.g., brief psychodynamic psychotherapies, ${ }^{90,91}$ cognitivebehavioral,,${ }^{92,93}$ mindfulness ${ }^{94-96}$ and attachment-based therapies), ${ }^{97}$ have demonstrated efficacy in other settings and warrant testing, including modularization to meet the individual needs of infants and their families. ${ }^{98}$ Evaluation of psychologically-informed, family-centered practices, ${ }^{34}$ tailored to the intensive care unit ecosystem, should be grounded in interdisciplinary teamwork to optimize care coordination and consistency. Structured psychosocial screening and mental health assessment using validated tools ${ }^{99}$ is recommended as part of standard care to facilitate early detection of risk and resilience factors, maximize opportunities for proactive engagement with psychosocial services, and bolster national efforts to monitor and improve mental health care and outcomes for this vulnerable population. ${ }^{5,41,100}$ Integrated intervention approaches that view early medical adversity through an ecobiodevelopmental lens are likely to have the broadest impact, ${ }^{25,41}$ and specialized psycho-education ${ }^{101}$ and support of the developing infant-parent bond are strongly recommended to nurture healthy infant emotional, behavioral and neurocognitive development. ${ }^{102}$

To enhance the quality of research, recommendations include: (a) larger-scale trials of conceptually-driven intervention approaches, drawing on multi-site collaborations to ensure adequate sample sizes with sufficient power to detect effects on parent, infant and family health; (b) use of structured clinical interviewing, alongside validated biobehavioral and psychometric measures, to derive nuanced and 
clinically-meaningful data; (c) longer periods of follow-up to test the sustainability of positive intervention effects, or new effects over time; (d) inclusion of active control conditions to minimize attentional bias; and (e) greater inclusion of diversity in terms of participant demographic, medical and sociocultural characteristics, to maximize generalizability of results and facilitate development of scalable interventions with the broadest possible reach and impact. In the current era of registries, the 'trial within a registry' method $^{103}$ may leverage data collection, reduce trial costs, and maximize generalizability of findings across clinical settings. To optimize potential for intervention efficacy, ${ }^{104}$ and increase transparency and replicability, future trials should also incorporate clearly-defined and pilot-tested intervention components, target symptoms and risk factors, structured interventionalist training and supervision, intervention manuals and standardized triage processes, and regular fidelity checks to ensure protocol adherence and high quality of care.

From a health policy perspective, exciting new initiatives with strong community and government engagement are underway in many parts of the world. Examples include Australia's National Strategic Action Plan for Childhood Heart Disease, ${ }^{105}$ the Congenital Heart Public Health Consortium workgroup on Neurodevelopment, Cognitive and Psychosocial Quality of Life (CHPHC CNP-Q) supported by the American Academy of Pediatrics (AAP) and the Centers for Disease Control and Prevention (CDC), ${ }^{106}$ and care consensus recommendations from the Association for European Paediatric and Congenital Cardiology (AEPC) Psychosocial Working Group. ${ }^{107}$ All such initiatives have a unified focus on addressing knowledge, practice and policy gaps, and utilize public health principles to affect change in the mental health outcomes of children with CHD and their families.

\section{CONCLUSIONS}

Congenital heart disease is a common cause of infant admission to pediatric intensive care and is associated with profound psychological stress for mothers, fathers and their infants. Intensive care unit admission represents an opportunity to offer evidence-based strategies to prevent or minimize severe psychological distress and promote infant development and secure infant-parent bonding, alongside high-quality infant medical care. This systematic review appraised published evidence on the efficacy and cost-effectiveness 
of mental health interventions delivered in neonatal, pediatric or cardiac intensive care units for parents of infants with a structural congenital anomaly requiring surgery. While the findings, derived from only five controlled trials, provide preliminary support for the efficacy of psychological interventions in reducing parental anxiety and improving coping, parenting confidence, satisfaction with clinical care, parent-infant attachment and infant mental development, there is still much work needed to strengthen the evidence base and develop robust best practice recommendations.

\section{REFERENCES}

1. van der Linde D, Konings EE, Slager MA, et al. Birth prevalence of congenital heart disease worldwide: A systematic review and meta-analysis. Journal of the American College of Cardiology. 2011;58(21):2241-2247.

2. Australian and New Zealand Intensive Care Society. Report of the Australian and New Zealand Paediatric Intensive Care Registry (ANZPIC). Brisbane: Centre for Outcome and Resource Evaluation;2014.

3. Australian Institute of Health and Welfare. A Picture of Australia's Children 2012. Cat. No. PHE 167. Canberra: AIHW;2012.

4. Australian Institute of Health and Welfare. Australian Burden of Disease Study: Impact and causes of illness and death in Australia 2011. Australian Burden of Disease Study Series No. 3. Cat. No. BOD 4. Canberra: AIHW;2016.

5. Denniss DL, Sholler GF, Costa DSJ, Winlaw DS, Kasparian NA. Need for routine screening of health-related quality of life in families of young children with complex congenital heart disease. The Journal of Pediatrics. 2019;205:21-28.e22.

6. Tweddell JS, Hoffman GM. Postoperative management in patients with complex congenital heart disease. Seminars in Thoracic and Cardiovascular Surgery: Pediatric Cardiac Surgery Annual. 2002;5:187-205.

7. Faraoni D, Nasr VG, DiNardo JA. Overall hospital cost estimates in children with congenital heart disease: Analysis of the 2012 Kid's Inpatient Database. Pediatric Cardiology. 2016;37(1):37-43.

8. McClung N, Glidewell J, Farr SL. Financial burdens and mental health needs in families of children with congenital heart disease. Congenit Heart Disease. 2018;13(4):554-562. 
9. Owen M, Shevell M, Donofrio M, et al. Brain volume and neurobehavior in newborns with complex congenital heart defects. The Journal of Pediatrics. 2014;164(5):1121.e1121-1127.e1121.

10. Massaro AN, Glass P, Brown J, et al. Neurobehavioral abnormalities in newborns with congenital heart disease requiring open-heart surgery. The Journal of Pediatrics. 2011;158:678-681.

11. Hartman DM, Medoff-Cooper B. Transition to home after neonatal surgery for congenital heart disease. MCN The American Journal of Maternal Child Nursing. 2012;37(2):95-100.

12. McKean EB, Kasparian NA, Batra S, Sholler GF, Winlaw DS, Dalby-Payne J. Feeding difficulties in neonates following cardiac surgery: Determinants of prolonged feeding-tube use. Cardiology in the Young. 2017;27(6):1203-1211.

13. Licht DJ, Shera DM, Clancy RR WG, et al. Brain maturation is delayed in infants with complex congenital heart defects. Journal of Thoracic \& Cardiovascular Surgery. 2009;137(3):529-536.

14. Wernovsky G, Licht DJ. Neurodevelopmental outcomes in children with congenital heart disease: What can we impact? Pediatric Critical Care Medicine. 2016;17(8):S232-S242.

15. Limperopoulos C, Majnemer A, Shevell MR, B, Rohlicek CT, C Neurodevelopmental status of newborns and infants with congenital heart defects before and after open heart surgery. Journal of Pediatrics. 2000;137(5):638-645.

16. Gaynor JW, Stopp C, Wypij D, et al. Neurodevelopmental outcomes after cardiac surgery in infancy. Pediatrics. 2015;135:816-825.

17. Verrall C, Blue G, Loughran-Fowlds A, et al. 'Big issues' in neurodevelopment in congenital heart disease. Open Heart. 2019;6:e00998.

18. Marino BS, Lipkin PH, Newburger JW, et al. Neurodevelopmental outcomes in children with congenital heart disease: Evaluation and management. A scientific statement from the American Heart Association. Circulation. 2012;126(9):1143-1172.

19. Wilson WM, Smith-Parrish M, Marino BS, Kovacs AH. Neurodevelopmental and psychosocial outcomes across the congenital heart disease lifespan. Progress in Pediatric Cardiology. 2015;39:113-118.

20. Gaynor JW, Ittenbach RF, Gerdes M, et al. Neurodevelopmental outcomes in preschool survivors of the Fontan procedure. Journal of Thoracic \& Cardiovascular Surgery. 2014;147(4):1276-1282. 
21. Mebius MJ, Kooi EMW, Bilardo CM, Bos AF. Brain injury and neurodevelopmental outcome in congenital heart disease: A systematic review. Pediatrics. 2017;140(1):e20164055.

22. Massaro AN, El-dib M, Glass P, Aly H. Factors associated with adverse neurodevelopmental outcomes in infants with congenital heart disease. Brain and Development. 2008;30(7):437-446.

23. Naguib AN, Winch PD, Tobias JD, et al. Neurodevelopmental outcome after cardiac surgery utilizing cardiopulmonary bypass in children. Saudi Journal of Anaesthesia. 2015;9(1):12-18.

24. Blue GM, Kirk EP, Giannoulatou E, et al. Advances in the genetics of congenital heart disease. Journal of the American College of Cardiology. 2017;69(7):859-870.

25. Shonkoff JP, Garner AS, Committee on Psychosocial Aspects of Child and Family Health, Committee on Early Childhood AaDC, Section on Developmental and Behavioral Pediatrics. The lifelong effects of early childhood adversity and toxic stress. Pediatrics. 2012;129(1):e232-e246.

26. Weber A, Harrison TM. Reducing toxic stress in the neonatal intensive care unit to improve infant outcomes. Nursing Outlook. 2018:In Press.

27. Shoemark H, Harcourt E, Arnup SJ, Hunt RW. Characterising the ambient sound environment for infants in intensive care wards. Journal of Paediatrics and Child Health. 2016;52(4):436-440.

28. Frie J, Bartocci M, Lagercrantz H, Kuhn P. Cortical responses to alien odors in newborns: An fNIRS study. Cerebral Cortex. 2017;28(9)::3229-3240.

29. Newnham CA, Inder TE, Milgrom J. Measuring preterm cumulative stressors within the NICU: the Neonatal Infant Stressor Scale. Early Human Development. 2009;85(9):549-555.

30. Carbajal R, Rousset A, Danan C, et al. Epidemiology and treatment of painful procedures in neonates in intensive care units. JAMA 2008;300(1):60-70.

31. Daniels JM, Harrison TM. A case study of the environmental experience of a hospitalized newborn infant with complex congenital heart disease. The Journal of Cardiovascular Nursing. 2016;31(5):390-398.

32. Gonya J, Nelin LD. Factors associated with maternal visitation and participation in skin-to-skin care in an all referral level IIIc NICU. Acta Paediatr. 2013;102(2):e53-e56.

33. Whetten CH. Cue-based feeding in the NICU. Nursing for Women's Health. 2016;20(5):507-510. 
34. Lisanti AJ, Vittner D, Medoff-Cooper B, Fogel J, Wernovsky G, Butler S. Individualized familycentered developmental care: An essential model to address the unique needs of infants with congenital heart disease. Journal of Cardiovascular Nursing: 2019;34:85-93.

35. Woolf-King SE, Anger A, Arnold AE, Weiss SJ, Teitel D. Mental health among parents of children with critical congenital heart defects: A systematic review. Journal of the American Heart Association. 2017;6:e004862.

36. Franck LS, McQuillan A, Wray J, Grocott MPW, Goldman A. Parent stress levels during children's hospital recovery after congenital heart surgery. Pediatric Cardiology. 2010;31(7):961-968.

37. Wray J, Lee K, Dearmun N, Franck L. Parental anxiety and stress during children's hospitalisation: The StayClose study. Journal of Child Health Care. 2011;15(3):163-174.

38. Khairy P, Ionescu-Ittu R, Mackie AS, Abrahamowicz M, Pilote L, Marelli AJ. Changing mortality in congenital heart disease. Journal of the American College of Cardiology. 2010;56:1149-1157.

39. Rychik J, Donaghue D, Levy S, et al. Maternal psychological stress after prenatal diagnosis of congenital heart disease. The Journal of Pediatrics. 2013;162:302-307.

40. Brosig CL, Whitstone BN, Frommelt MA, Frisbee SJ, Leuthner SR. Psychological distress in parents of children with severe congenital heart disease: the impact of prenatal versus postnatal diagnosis. Journal of Perinatology. 2007;27(11):687-692.

41. Kasparian NA, Winlaw DS, Sholler GF. 'Congenital heart health': How psychological care can make a difference. The Medical Journal of Australia. 2016;205(3):104-106.

42. Pinelli J, Saigal S, Wu Y, et al. Patterns of change in family functioning, resources, coping and parental depression in mothers and fathers of sick newborns over the first year of life. J Neonatal Nurs. 2008;14:156-165.

43. Bergstrom E, Wallin L, Thomson G, Flacking R. Postpartum depression in mothers of infants cared for in a neonatal intensive care unit-Incidence and associated factors. $J$ Neonatal Nurs. 2012;18(4):143-151.

44. Kasparian NA. Health care before birth: A psychobiological perspective on fetal cardiac diagnosis. Progress in Pediatric Cardiology. In Press. 
45. Diffin J, Spence K, Naranian T, Badawi N, Johnston L. Stress and distress in parents of neonates admitted to the neonatal intensive care unit for cardiac surgery. Early human development. 2016;103:101-107.

46. Lisanti AJ, Allen LR, Kelly L, Medoff-Cooper B. Maternal stress and anxiety in the pediatric cardiac intensive care unit. American Journal of Critical Care. 2017;26(2):118-125.

47. Affleck G, Tennen H, Rowe J. Infants in crisis: How parents cope with newborn intensive care and its aftermath. New York: Springer-Verlag; 1991.

48. Board R. Father stress during a child's critical care hospitalization. Journal of Pediatric Health Care. 2004;18:244-249.

49. Board R, Ryan-Wenger N. Stressors and stress symptoms of mothers with children in the PICU. Journal of Pediatric Nursing. 2003;18:195-202.

50. Seideman RY, Watson MA, Corff KE, Odle P, Haase J, Bowerman JL. Parent stress and coping in NICU and PICU. Journal of Pediatric Nursing. 1997;12:169-177.

51. Padley JR, Cole AD, Pye VE, et al. Five-year analysis of operative mortality and neonatal outcomes in congenital heart disease. Heart, Lung \& Circulation. 2011;20(7):460-467.

52. Schwalbe-Terilli CR, Hartman DH, Nagle ML. Enteral feeding and caloric intake in neonates after cardiac surgery. American Journal of Critical Care. 2009;18:52-57.

53. Goldberg S, Morris P, Simmons RJ, Fowler RS, et al. Chronic illness in infancy and parenting stress: A comparison of three groups of parents. Journal of Pediatric Psychology. 1990;15(3):347358.

54. Lawoko S, Soares JJF. Distress and hopelessness among parents of children with congenital heart disease, parents of children with other diseases, and parents of healthy children. J Psychosom Res 2002;52(4):193-208

55. Kasparian NA, Barnett BE, Winlaw D KE, Sholler GFS. When hearts and minds meet: A psychological perspective on fetal cardiac diagnosis. Infant Mental Health Journal 2010;32(3):104.

56. Leigh B, Milgrom J. Risk factors for antenatal depression, postnatal depression and parenting stress. BMC Psychiatry. 2008;8:24. 
57. Lancaster CA, Gold KJ, Flynn HA, Yoo H, Marcus SM, Davis MM. Risk factors for depressive symptoms during pregnancy: A systematic review. American Journal of Obstetrics and Gynecology. 2010;202(1):5-14.

58. Lawoko S. Factors influencing satisfaction and well-being among parents of congenital heart disease children: Development of a conceptual model based on the literature review. Scand $J$ Caring Sci. 2007;21(1):106-117.

59. Werner H, Latal B, Valsangiacomo Buechel E, Beck I, Landolt MA. The impact of an infant's severe congenital heart disease on the family: A prospective cohort study. Congenit Heart Dis. 2013.

60. Ernst MM, Marino BS, Cassedy A, et al. Biopsychosocial predictors of quality of life outcomes in pediatric congenital heart disease. Pediatr Cardiol. 2018;39:79-88.

61. Laplante DP, Barr RG, Brunet A, et al. Stress during pregnancy affects general intellectual and language functioning in human toddlers. Pediatr Res. 2004;56(3):400-410.

62. Visconti KJ, Saudino KJ, Rappaport LA, Newburger JW, Bellinger DC. Influence of parental stress and social support on the behavioral adjustment of children with transposition of the great arteries. Journal of Developmental \& Behavioral Pediatrics. 2002;23(5):314-321.

63. McCusker CG, Doherty NN, Molloy B, et al. Determinants of neuropsychological and behavioural outcomes in early childhood survivors of congenital heart disease. Archives of Disease in Childhood. 2007;92(2):137-141.

64. Mendelson T, Cluxton-Keller F, Vullo GC, Tandon D, Noazin S. NICU-based interventions to reduce maternal depressive and anxiety symptoms: A meta-analysis. Pediatrics. 2017;139(3):e20161870.

65. Chertok IR, McCrone S, Parker D, Leslie N. Review of interventions to reduce stress among mothers of infants in the NICU. Advances in Neonatal Care. 2014;14(1):30-37.

66. Sood E, Berends WM, Butcher JL, et al. Developmental care in North American pediatric cardiac intensive care units: Survey of current practices. Advances in Neonatal Care. 2016;16(3):211-219.

67. Moher D, Liberati A, Tetzlaff J, Altman DG, Group P. Preferred reporting items for systematic reviews and meta-analyses: the PRISMA statement. PLoS Medicine. 2009;6(7):e1000097. 
68. Tesson S, Butow PN, Sholler GF, Sharpe L, Kovacs AH, Kasparian NA. Psychological interventions for people affected by childhood-onset heart disease: A systematic review. Health Psychol. 2018:In Press.

69. Higgins JPT, Green S, eds. Cochrane Handbook for Systematic Reviews of Interventions Version 5.1.0. The Cochrane Collaboration: Available from http://handbook.cochrane.org; 2011.

70. Kirkham JJ, Altman DG, Williamson PR. Bias due to changes in specified outcomes during the systematic review process. PloS One. 2010;5(3):e9810.

71. Higgins JPT, Altman DG, Gøtzsche PC, et al. The Cochrane Collaboration's tool for assessing risk of bias in randomised trials. British Medical Journal. 2011;343:d5928.

72. Sterne JAC, Hernán MA, Reeves BC, et al. ROBINS-I: A tool for assessing risk of bias in nonrandomised studies of interventions. British Medical Journal. 2016;355:i4919.

73. Guyatt GH, Oxman AD, Schünemann HJ, Tugwell P, Knottnerus A. GRADE guidelines: A new series of articles. J Clin Epidemiol. 2011;64(4):380-394.

74. Borenstein M, Hedges L, Higgins JP, (2009). RH. Introduction to Meta-Analysis. Chicester: John Wiley \& Sons, Ltd; 2009.

75. McCusker CG, Doherty NN, Molloy B, et al. A controlled trial of early interventions to promote maternal adjustment and development in infants born with severe congenital heart disease. Child Care Health Dev. 2010;36(1):110-117.

76. Cano-Giménez E, Sanchez-Luna M. Providing parents with individualised support in a neonatal intensive care unit reduced stress, anxiety and depression. Acta Padiatrica. 2015;104(7):e300-305.

77. Hancock HS, Pituch K, Uzark K, et al. A randomised trial of early palliative care for maternal stress in infants prenatally diagnosed with single-ventricle heart disease. Cardiology in the Young. 2018;28:561-570.

78. Jabraili M, Rasouli AS, Qojazadeh M, Abadi SH. The impact of support programs on attachment of mothers of infants with gastrointestinal disorders: A randomized controlled clinical trial. 2017;10(6):1613-1618.

79. Uhm J-Y, Kim HS. Impact of the mother-nurse partnership programme on mother and infant outcomes in paediatric cardiac intensive care unit. Intensive and Critical Care Nursing. 2019;50:79-87. 
80. Kosta L, Harms L, Franich-Ray C, et al. Parental experiences of their infant's hospitalization for cardiac surgery. Child 2015;41 (6):1057-1065.

81. Franich-Ray C, Bright MA, Anderson V, et al. Trauma reactions in mothers and fathers after their infant's cardiac surgery. Journal of Pediatric Psychology. 2013;38(5):494-505.

82. Cantwell-Bartl AM, Tibballs J. Psychosocial experiences of parents of infants with hypoplastic left heart syndrome in the PICU. Pediatric Critical Care Medicine. 2013;14(9):869-875.

83. Diffin J, Spence K, Naranian T, Badawi N, Johnston L. Stress and distress in parents of neonates admitted to the neonatal intensive care unit for cardiac surgery. Early Human Development. 2016;103:101-107.

84. Prouhet PM, Gregory MR, Russell CL, Yaeger LH. Fathers' Stress in the Neonatal Intensive Care Unit: A Systematic Review. Advances in Neonatal Care. 2018;18(2):105-120.

85. Seidler ZE, Rice SM, River J, Oliffe JL, Dhillon HM. Men's mental health services: The case for a masculinities model. The Journal of Men's Studies. 2018;26(1):92-104.

86. Seidler ZE, Dawes AJ, Rice SM, Oliffe JL, Dhillon HM. The role of masculinity in men's helpseeking for depression: A systematic review. Clinical Psychology Review. 2016;49:106-118.

87. Seidler ZE, Rice SM, Ogrodniczuk JS, Oliffe JL, Dhillon HM. Engaging men in psychological treatment: A scoping review. American Journal of Men's Health. 2018;12(6):1882-1900.

88. Demianczyk AC, Behere SP, Thacker D, et al. Social risk factors impact hospital readmission and outpatient appointment adherence for children with congenital heart disease. Journal of Pediatrics. 2019;205:35-40.e31.

89. Institute of Medicine. Psychosocial Interventions for Mental and Substance Use Disorders: A Framework for Establishing Evidence-Based Standards. Washington, DC: The National Academies Press;2015.

90. Steinert C, Munder T, Rabung S, Hoyer J, Leichsenring F. Psychodynamic therapy: As efficacious as other empirically-supported treatments? A meta-analysis testing equivalence of outcomes. American Journal of Psychiatry. 2017;174:943-953.

91. Leichsenring F, Rabung S, Leibing E. The efficacy of short-term psychodynamic psychotherapy in specific psychiatric disorders: A meta-analysis. Archives of General Psychiatry. 2004;61:12081216. 
92. Sockol LE. A systematic review of the efficacy of cognitive behavioral therapy for treating and preventing perinatal depression. Journal of Affective Disorders. 2015;177:7-21.

93. Maguire PN, Clark GI, Wootton BM. The efficacy of cognitive behavior therapy for the treatment of perinatal anxiety symptoms: A preliminary meta-analysis. Journal of Anxiety Disorders. 2018;60:26-34.

94. Hofmann SG, Sawyer AT, Witt AA, Oh D. The effect of mindfulness-based therapy on anxiety and depression: A meta-analytic review. Journal of Consulting and Clinical Psychology. 2010;78(2):169-183.

95. Fjorback LO, Arendt M, Ørnbøl E, Fink P, Walach H. Mindfulness-based stress reduction and mindfulness-based cognitive therapy: A systematic review of randomized controlled trials. Acta Psychiatrica Scandinavica. 2011;124(2):102-119.

96. Khoury B, Lecomte T, Fortin G, et al. Mindfulness-based therapy: A comprehensive meta-analysis. Clinical Psychology Review. 2013;33(6):763-771.

97. Diamond G, Russon J, Levy S. Attachment-based family therapy: A review of the empirical support. Family Process. 2016;55(3):595-610.

98. Fonagy P. The effectiveness of psychodynamic psychotherapies: An update. World Psychiatry. 2015;14(2):137-150.

99. Kazak AE, Barakat LP, Ditaranto S, et al. Screening for psychosocial risk at pediatric cancer diagnosis: the psychosocial assessment tool. J Pediatr Hematol Oncol. 2011;33(4):289-294.

100. Yawn B, Olson A, al. e. Postpartum depression: Screening, diagnosis, and management programs 2000 through 2010. Depression Research and Treatment 2012:1-9.

101. Tesson S, Butow PN, Sholler GF, Sharpe L, Kovacs AH, Kasparian NA. Childhood-onset heart disease and psychological intervention: A systematic review. Health Psychol. 2019:In Press.

102. Jordan B, Franich-Ray C, Northam E, Albert N, Cochrane A, Menahem S. Early mother-infant relationships after cardiac surgery in infancy. Archives of Disease in Childhood. 2014;99:641-645.

103. Lauer MS, D'Agostino RB. The randomized registry trial: The next disruptive technology in clinical research? N Engl J Med. 2013;369:1579-1581. 
104. Levati S, Campbell P, Frost R, et al. Optimisation of complex health interventions prior to a randomised controlled trial: A scoping review of strategies used. Pilot and Feasibility Studies. 2016;2:17.

105. Commonwealth of Australia (Department of Health). National Strategic Action Plan for Childhood Heart Disease: Beyond the heart, transforming care. 2019;

https://www.heartkids.org.au/congenital-heart-disease/national-strategic-action-plan-for-chd/chdaction-plan.

106. Jenkins KJ, Botto LD, Correa A, et al. Public health approach to improve outcomes for congenital heart disease across the life span. Journal of the American Heart Association. 2019;8:e009450.

107. Utens E, Callus E, Levert E, De Groote K, Casey F. Multidisciplinary family-centred psychosocial care for patients with CHD: Consensus recommendations from the AEPC Psychosocial Working Group. Cardiology in the Young. 2017;28(2):1-7. 


\section{STRESSORS IN THE PSYCHOSOCIAL ENVIRONMENT DURING INTENSIVE CARE UNIT ADMISSION}

\section{PARENTS}

- Difficult, time-sensitive medical decisions.

- Intense feelings of sadness, anger, guilt and shame.

- Fear of infant suffering or death.

- Disruptions to bonding and attachment.

- Disruptions to developing sense of self as a parent.

- Fears relating to infant's appearance and medical care.

- Bearing witness to painful procedures or traumatic events.

- Alterations in parental role.

- Periods of separation from their infant.

- Difficulties with cliniciancaregiver communication.

- Uncertainty about the future and infant's prognosis.

- Psychological stress and distress.

- Grief and loss.

- Psychiatric disturbance, including higher rates of perinatal anxiety, depression, and post-traumatic stress disorder.

- Deterioration in physical health (e.g. disrupted circadian regulation, poor nutrition, fatigue).

\section{INFANTS}

- Limited opportunity for attuned, developmentallysensitive interaction with caregivers.

- Disruptions to infant-parent bonding.

- Heightened sensitivity to light, sound, smell and touch.

- Feeding, sleeping, soothing and settling difficulties.

- Exposure to frightening or painful clinical interventions.

- Emotional, behavioral and neurobiological dysregulation.

- Vulnerability to neurodevelopmental impairment, particularly fine and gross motor skills delay.

- Higher incidence of insecure patterns of attachment.

- Delirium

- Opioid withdrawal.

\section{FAMILIES}

- Disruptions to routine family functioning.

- Separation from family members, particularly for families who live far from the treating hospital or who do not have access to paid leave.

- Altered opportunities to introduce and share their infant and parenting experiences with family and friends.

- Social withdrawal.

- Family conflict and communication difficulties.

- Mismatches in coping responses between family members.

- Dyadic relationship strain.

- Emotional and behavioral difficulties in siblings, including manifestations of worry, anger, guilt, envy and a sense of rejection or abandonment.

- Difficulties understanding medical information.

- Financial strain.

Figure 1. Stressors in the psychosocial environment for infants with CHD during intensive care unit admission, and their parents and family members. 


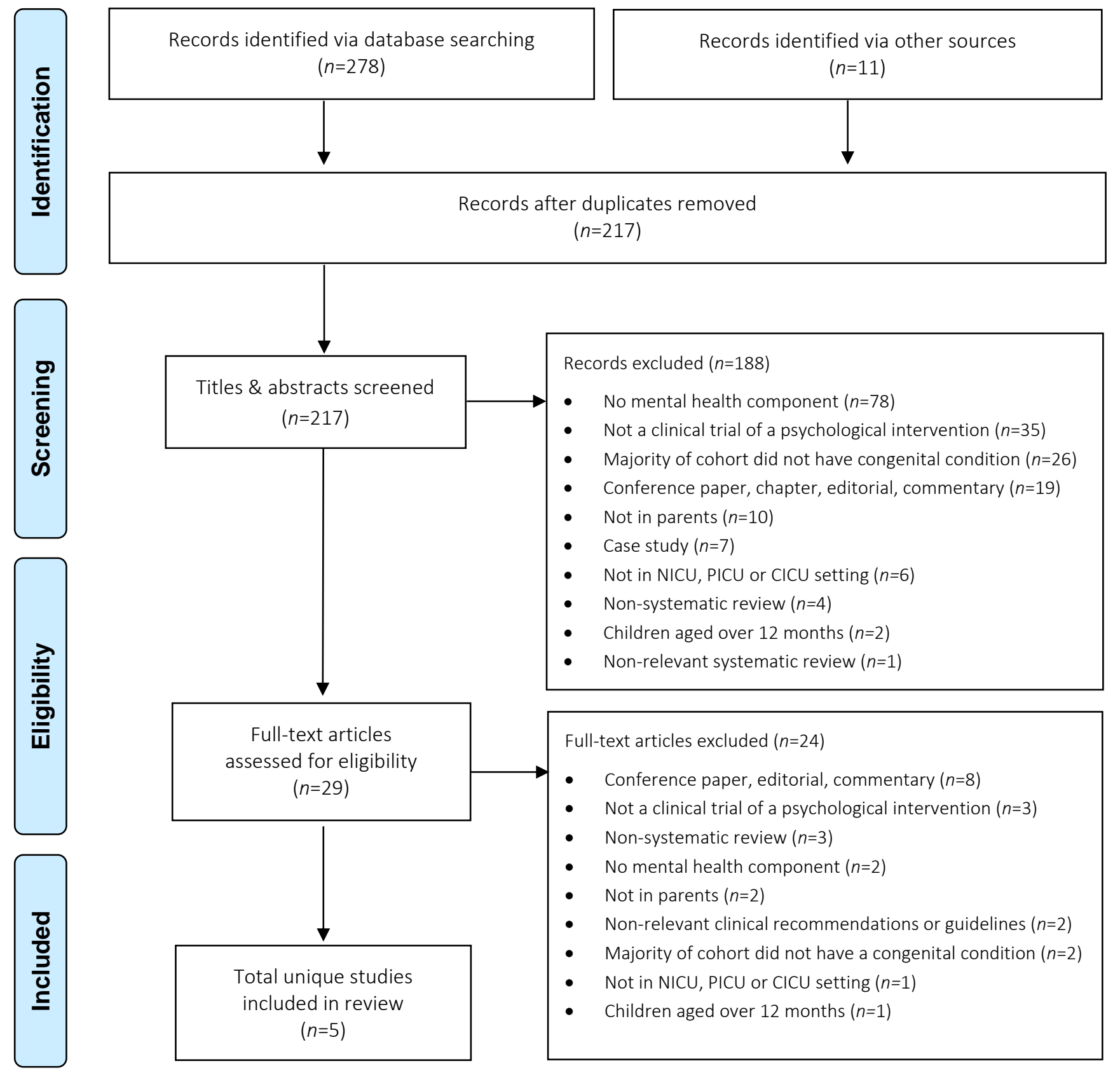

Figure 2. PRISMA diagram illustrating the systematic search process. 


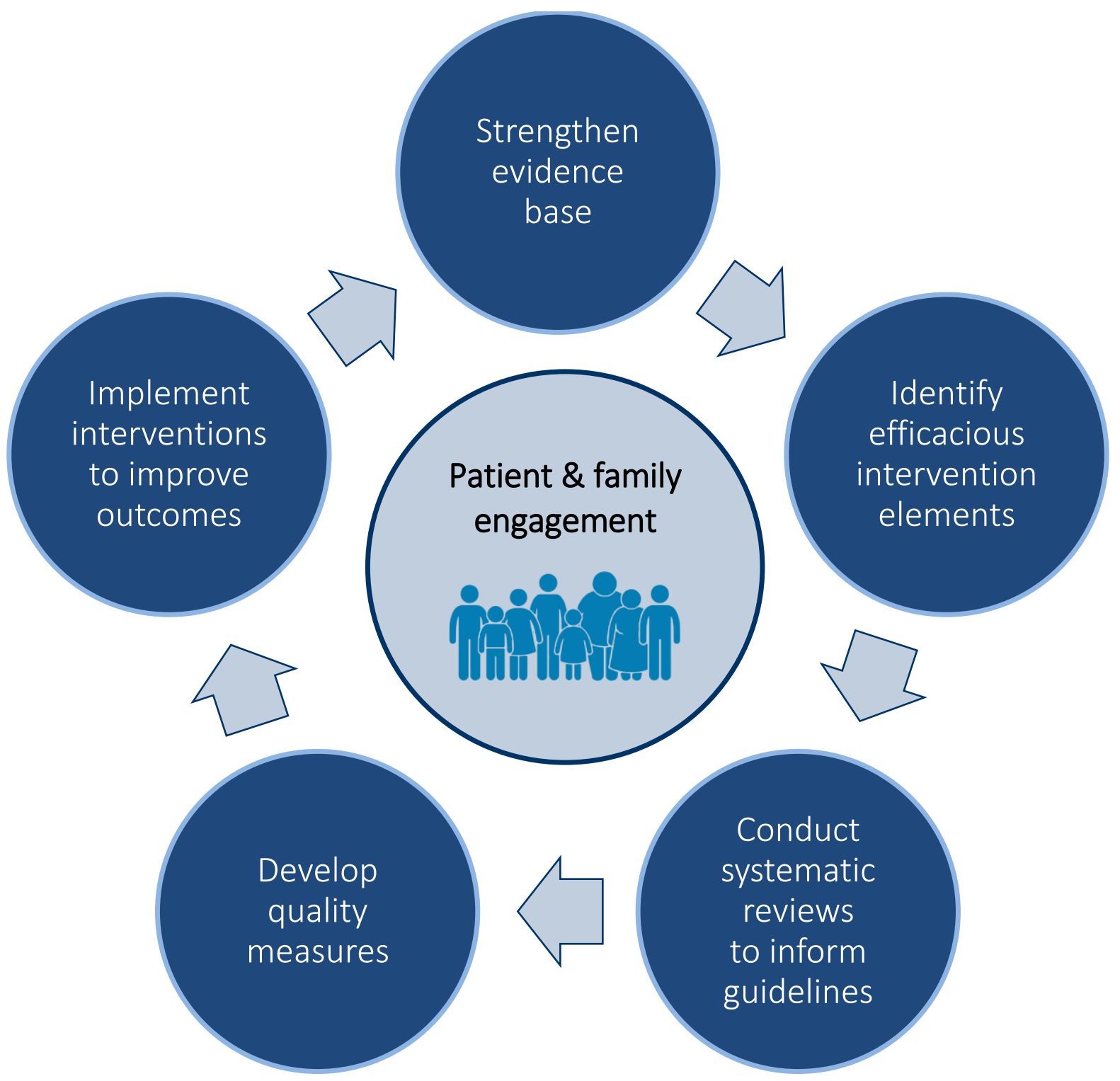

Figure 3. Framework for developing standards for mental health interventions, adapted from the National Academy of Sciences. ${ }^{89}$ 
Table 1. Characteristics of trials of mental health interventions for parents of infants with congenital heart disease requiring intensive care unit admission ( $N=5$ ).

\begin{tabular}{|c|c|c|c|c|c|c|c|c|c|c|c|}
\hline \multirow{2}{*}{$\begin{array}{l}\text { First Author, } \\
\text { Publication } \\
\text { Year \& } \\
\text { Article Title }\end{array}$} & \multirow[b]{2}{*}{$\begin{array}{l}\text { Country } \\
\text { \& Setting }\end{array}$} & \multirow[b]{2}{*}{$\begin{array}{l}\text { Congenital } \\
\text { Anomaly } \\
\text { \& Infant Age }\end{array}$} & \multirow[b]{2}{*}{$\begin{array}{l}\text { Trial Design } \\
\text { \& Registration }\end{array}$} & \multirow[b]{2}{*}{$\begin{array}{l}\text { Participants } \\
\text { \& Response } \\
\text { Rates }\end{array}$} & \multicolumn{2}{|c|}{ Sample Size } & \multicolumn{3}{|c|}{ Demographic and Clinical Characteristics } & \multirow[b]{2}{*}{$\begin{array}{l}\text { Control } \\
\text { Condition }\end{array}$} & \multirow[b]{2}{*}{ Procedure } \\
\hline & & & & & $\begin{array}{l}\text { Intervention } \\
\text { (Baseline, } \\
\text { Follow-Up) }\end{array}$ & $\begin{array}{c}\text { Control } \\
\text { (Baseline, } \\
\text { Follow-Up) }\end{array}$ & Intervention Group & Control Group & $\begin{array}{c}\text { Group } \\
\text { Differences }\end{array}$ & & \\
\hline $\begin{array}{l}\text { McCusker } \\
\text { et al. } 2010 \\
\\
\text { A controlled } \\
\text { trial of early } \\
\text { interventions } \\
\text { to promote } \\
\text { maternal } \\
\text { adjustment } \\
\text { and } \\
\text { development } \\
\text { in infants } \\
\text { born with } \\
\text { severe } \\
\text { congenital } \\
\text { heart disease }\end{array}$ & $\begin{array}{l}\text { Belfast, } \\
\text { Northern } \\
\text { Ireland } \\
\text { Regional } \\
\text { pediatric } \\
\text { cardiac } \\
\text { unit }\end{array}$ & $\begin{array}{l}\text { Congenital } \\
\text { heart } \\
\text { disease } \\
\text { Mean infant } \\
\text { age at } \\
\text { baseline } \\
2.9 \pm 1.6 \\
\text { months }\end{array}$ & $\begin{array}{c}\text { Non- } \\
\text { randomized } \\
\text { controlled } \\
\text { trial } \\
\text { Families } \\
\text { allocated to } \\
\text { INT }(n=35) \text { or } \\
\text { CON }(n=35) \text { in } \\
\text { blocks of 10, } \\
\text { based on } \\
\text { order of unit } \\
\text { admission. } \\
\text { Registration: } \\
\text { NR }\end{array}$ & $\begin{array}{c}70 \text { families } \\
\text { (70 mothers, } \\
56 \text { fathers) } \\
\text { Response } \\
\text { rate: } \\
96 \% \\
\text { Attrition: } \\
23 \% \\
\text { (higher in } \\
\text { CON vs INT } \\
\text { group) }\end{array}$ & $\begin{array}{l}\text { Baseline: } \\
\quad \mathrm{n}=35 \\
\text { Follow-up: } \\
\quad \mathrm{n}=31 \\
\text { (mothers) }\end{array}$ & $\begin{array}{l}\text { Baseline: } \\
\quad \mathrm{n}=35 \\
\text { Follow-up: } \\
\mathrm{n}=23 \\
\text { (mothers) }\end{array}$ & 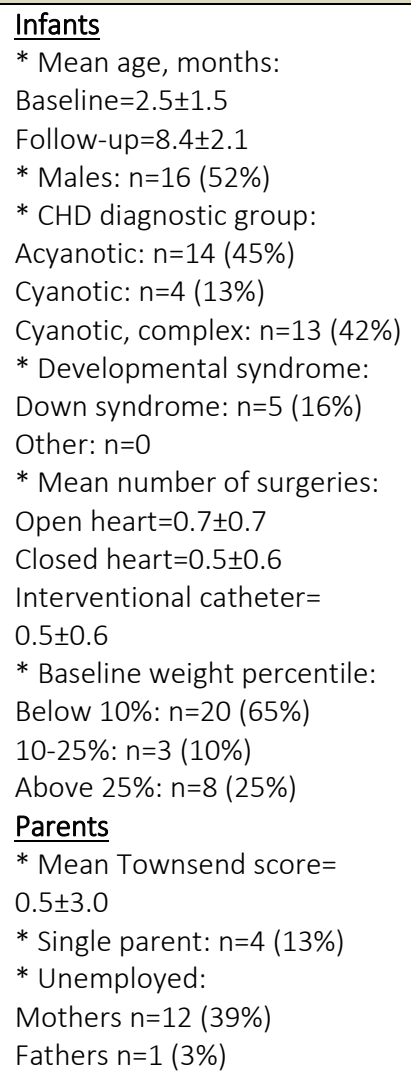 & 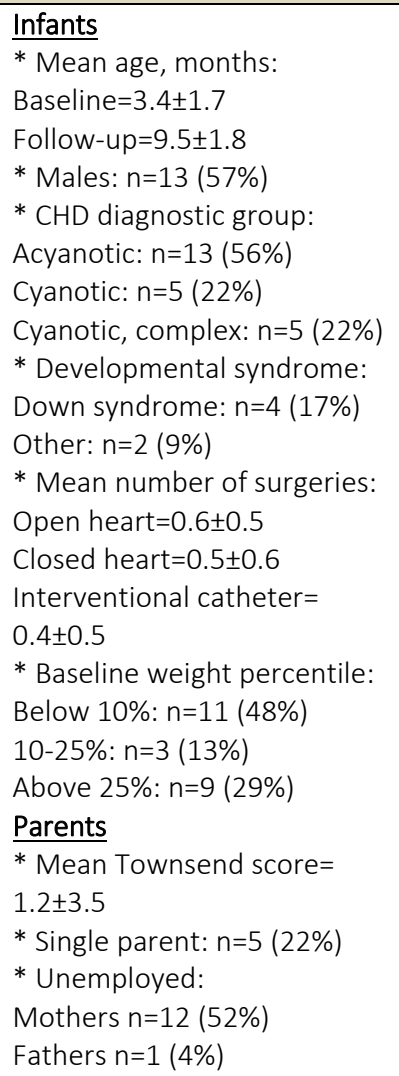 & $\begin{array}{l}\text { Infant age at } \\
\text { baseline } \\
\text { differed } \\
\text { between } \\
\text { groups } \\
(p=0.04) ; \\
\text { included in } \\
\text { analyses as } \\
\text { a covariate. }\end{array}$ & 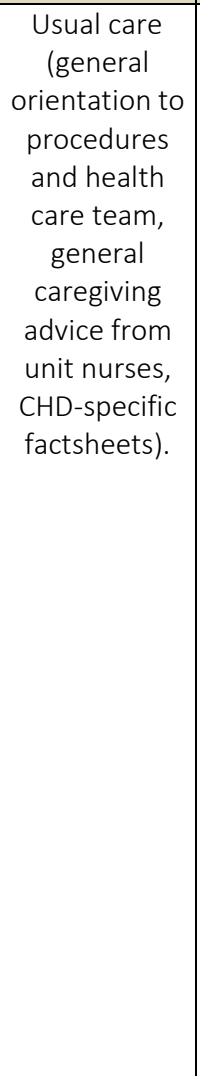 & $\begin{array}{c}\text { Parents of } \\
\text { infants with } \\
\text { CHD requiring } \\
\text { cardiac } \\
\text { surgery or } \\
\text { interventional } \\
\text { catheter } \\
\text { invited to } \\
\text { participate } \\
\text { within 2 } \\
\text { weeks of } \\
\text { admission. }\end{array}$ \\
\hline
\end{tabular}




\begin{tabular}{|c|c|c|c|c|c|c|c|c|c|c|c|}
\hline $\begin{array}{l}\text { Cano-Giménez } \\
\text { et al. } 2015 \\
\\
\text { Providing } \\
\text { parents with } \\
\text { individualized } \\
\text { support in a } \\
\text { neonatal } \\
\text { intensive } \\
\text { care unit } \\
\text { reduced } \\
\text { stress, } \\
\text { anxiety and } \\
\text { depression }\end{array}$ & $\begin{array}{l}\text { Madrid, } \\
\text { Spain } \\
\text { NICU }\end{array}$ & $\begin{array}{c}\text { Congenital } \\
\text { heart disease } \\
n=19 \\
\text { (8 INT, } \\
11 \text { CON) } \\
\text { Hypoxic- } \\
\text { ischaemic } \\
\text { encephalo- } \\
\text { pathy } n=29 \\
\text { (16 INT, } \\
13 \text { CON) } \\
\text { Prematurity } \\
n=32 \\
\text { (16 INT, } \\
16 \text { CON) } \\
\text { Infant age: NR } \\
\text { (all neonates } \\
\text { immediately } \\
\text { admitted to } \\
\text { NICU) }\end{array}$ & $\begin{array}{l}\text { Non- } \\
\text { randomized } \\
\text { controlled trial } \\
\text { Participants } \\
\text { consecutively } \\
\text { assigned to } \\
\text { group in order } \\
\text { of NICU } \\
\text { admission } \\
\text { Registration: } \\
\text { NR }\end{array}$ & $\begin{array}{c}80 \text { families } \\
\text { (80 mothers, } \\
28 \text { fathers) } \\
\text { Response } \\
\text { rate: NR } \\
\text { Attrition: } \\
\text { fathers } 48 \% \text {, } \\
\text { mothers NR }\end{array}$ & $\begin{array}{l}\text { Mothers } \\
\mathrm{n}=40 \\
\text { Fathers } \\
\mathrm{n}=25 \\
\\
\text { (analysis } \\
\text { based on } 10 \\
\text { fathers) }\end{array}$ & $\begin{array}{c}\text { Mothers } \\
n=40 \\
\text { Fathers } \\
n=29 \\
\text { (analysis } \\
\text { based on } \\
18 \text { fathers) }\end{array}$ & $\begin{array}{l}\frac{\text { Infants }}{* \text { Mean birth order }=1.7 \pm 0.8} \\
\frac{\text { Parents }}{* \text { Mean age, years: }} \\
\text { Mothers }=33.9 \pm 6.4 \\
\text { Fathers }=34.9 \pm 6.5 \\
\text { * Mean educational } \\
\text { attainment: } \\
\text { Mothers }=4.1 \pm 1.0 \\
\text { Fathers }=3.9 \pm 1.1 \\
{[3=\text { studies finished at age } 15-} \\
16 \text { years, } 4=\text { secondary } \\
\text { education] } \\
\text { * Mean employment status: } \\
\text { Mothers }=1.4 \pm 0.5 \\
\text { Fathers }=1.1 \pm 0.3 \\
{[1=\text { active, } 2=\text { unemployed] }} \\
\text { * Mean number of children in } \\
\text { family=1.9 } \pm 0.9\end{array}$ & $\begin{array}{l}\frac{\text { Infants }}{* \text { Mean birth order }=1.5 \pm 0.68} \\
\frac{\text { Parents }}{* \text { Mean age, years: }} \\
\text { Mothers }=32.6 \pm 4.8 \\
\text { Fathers }=36.5 \pm 6.4 \\
* \text { Mean educational attainment: } \\
\text { Mothers }=4.1 \pm 0.8 \\
\text { Fathers }=3.9 \pm 1.1 \\
* \text { Mean employment status: } \\
\text { Mothers }=1.2 \pm 0.4 \\
\text { Fathers }=1.2 \pm 0.4 \\
* \text { Mean number of children in } \\
\text { family }=1.6 \pm 0.8\end{array}$ & $\mathrm{Nil}$ & $\begin{array}{l}\text { Usual care } \\
\text { (information } \\
\text { on infant's } \\
\text { medical } \\
\text { condition, } \\
\text { NICU } \\
\text { orientation, } \\
\text { guidance on } \\
\text { parent-baby } \\
\text { interaction, } \\
\text { emotional } \\
\text { support } \\
\text { provided by } \\
\text { NICU staff). }\end{array}$ & $\begin{array}{l}\text { Parents } \\
\text { consecutively } \\
\text { assigned to } \\
\text { INT or CON in } \\
\text { order of NICU } \\
\text { admission. } \\
\text { Controls } \\
\text { evaluated } \\
\text { first. } \\
\text { Groups } \\
\text { matched by } \\
\text { social factors. } \\
\text { After NICU } \\
\text { admission, } \\
\text { parents } \\
\text { completed } \\
\text { self-report } \\
\text { surveys. }\end{array}$ \\
\hline \begin{tabular}{|} 
Jabraili et al. \\
2017 \\
The impact \\
of support \\
programs on \\
attachment \\
of mothers \\
of infants \\
with gastro- \\
intestinal \\
disorders: A \\
randomized \\
controlled \\
clinical trial
\end{tabular} & $\begin{array}{l}\text { Tabriz, } \\
\text { Iran } \\
\text { NICU }\end{array}$ & $\begin{array}{l}\text { Congenital } \\
\text { gastro- } \\
\text { intestinal } \\
\text { malformation } \\
\text { requiring } \\
\text { surgery } \\
\text { Infant age } \\
\text { INT: } \\
\text { M=2.3 } \pm 5.2 \\
\text { weeks } \\
\text { CON: } \\
\text { M=2.2 } \pm 4.9 \\
\text { weeks }\end{array}$ & \begin{tabular}{|c|} 
Randomized \\
controlled trial \\
\\
Randomized \\
using Rand List \\
software \\
\\
Registration: Yes \\
(IRCT2014092 \\
64617N10) \\
\end{tabular} & $\begin{array}{l}50 \text { mothers } \\
\text { Response } \\
\text { rate: } 53 \% \\
\text { Attrition: } \\
\text { Nil reported }\end{array}$ & $\begin{array}{c}\text { Baseline: } \\
\quad n=25 \\
\text { Follow-up: } \\
\quad n=25\end{array}$ & $\begin{array}{c}\text { Baseline: } \\
\quad n=25 \\
\text { Follow-up: } \\
\text { n=25 }\end{array}$ & $\begin{array}{l}\frac{\text { Infants }}{\text { * Male }=16(64 \%)} \\
\text { Mothers } \\
\text { * Married: } n=24(96 \%) \\
\text { * Number of children: } \\
\text { One: } n=14(56 \%) \\
\text { Two: } n=5(20 \%) \\
\text { Three: } n=6(24 \%) \\
\text { * Education level: } \\
\text { Illiterate: } n=7(28 \%) \\
\text { Diploma or below: } n=13(52 \%) \\
\text { Undergraduate degree: } n=5 \\
\text { (20\%) } \\
\text { *Employed: } n=1(4 \%) \\
\text { *Support 'resources': } \\
\text { Husband: } n=24(96 \%) \\
\text { Father's family: } n=1(4 \%)\end{array}$ & $\begin{array}{l}\frac{\text { Infants }}{\text { * Male }=14(56 \%)} \\
\text { Mothers } \\
\text { * Married: } n=25(100 \%) \\
\text { * Number of children: } \\
\text { One: } n=17(68 \%) \\
\text { Two: } n=7(28 \%) \\
\text { Three: } n=1(4 \%) \\
\text { * Education level: } \\
\text { Illiterate: } n=3(12 \%) \\
\text { Diploma or below: } n=20(80 \%) \\
\text { Undergraduate degree: } n=2(8 \%) \\
\text { *Employed: } n=2(8 \%) \\
\text { *Support 'resources': } \\
\text { Husband: } n=25(100 \%)\end{array}$ & $\mathrm{Nil}$ & $\begin{array}{l}\text { Usual care. } \\
\text { After } \\
\text { completion } \\
\text { of trial data } \\
\text { collection, } \\
\text { mothers in } \\
\text { control } \\
\text { group } \\
\text { received a } \\
\text { copy of the } \\
\text { intervention } \\
\text { manual. }\end{array}$ & \begin{tabular}{|c}
\multicolumn{1}{|c}{ Mothers } \\
randomized \\
to receive INT \\
or usual care \\
(CON). \\
Self-reported \\
mother-infant \\
attachment \\
assessed on \\
study entry \\
and follow-up.
\end{tabular} \\
\hline
\end{tabular}




\begin{tabular}{|c|c|c|c|c|c|c|c|c|c|c|c|}
\hline 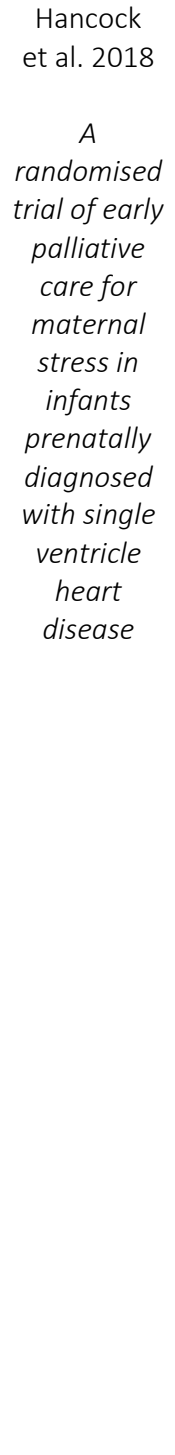 & $\begin{array}{l}\text { Michigan, } \\
\text { USA } \\
\text { Heart } \\
\text { Center } \\
\text { ICU } \\
\text { Recruited } \\
\text { during } \\
\text { pregnancy } \\
\text { INT } \\
\text { delivered } \\
\text { during } \\
\text { infant } \\
\text { hospital } \\
\text { admission }\end{array}$ & $\begin{array}{c}\text { Single } \\
\text { ventricle } \\
\text { congenital } \\
\text { heart } \\
\text { disease } \\
\text { Infant age: } \\
\text { NR } \\
\text { (neonates) }\end{array}$ & $\begin{array}{c}\text { Pilot } \\
\text { randomized } \\
\text { controlled trial } \\
\text { Randomized } \\
\text { by date of } \\
\text { birth (or NICU } \\
\text { admission) } \\
\text { in alternating } \\
\text { blocks of } 3 \\
\text { mothers per } \\
\text { block to INT } \\
\text { or CON } \\
\text { Registration: } \\
\text { Yes } \\
\text { (NCT02462434) }\end{array}$ & $\begin{array}{c}38 \text { mothers } \\
\text { referred to } \\
\text { congenital } \\
\text { heart center } \\
\text { Response } \\
\text { rate: } \\
71 \% \\
\text { Attrition: } \\
10 \%\end{array}$ & $\begin{array}{l}\text { Baseline: } \\
\quad n=18 \\
\text { Follow-up: } \\
n=17\end{array}$ & $\begin{array}{l}\text { Baseline: } \\
\qquad n=20 \\
\text { Follow-up: } \\
n=17\end{array}$ & 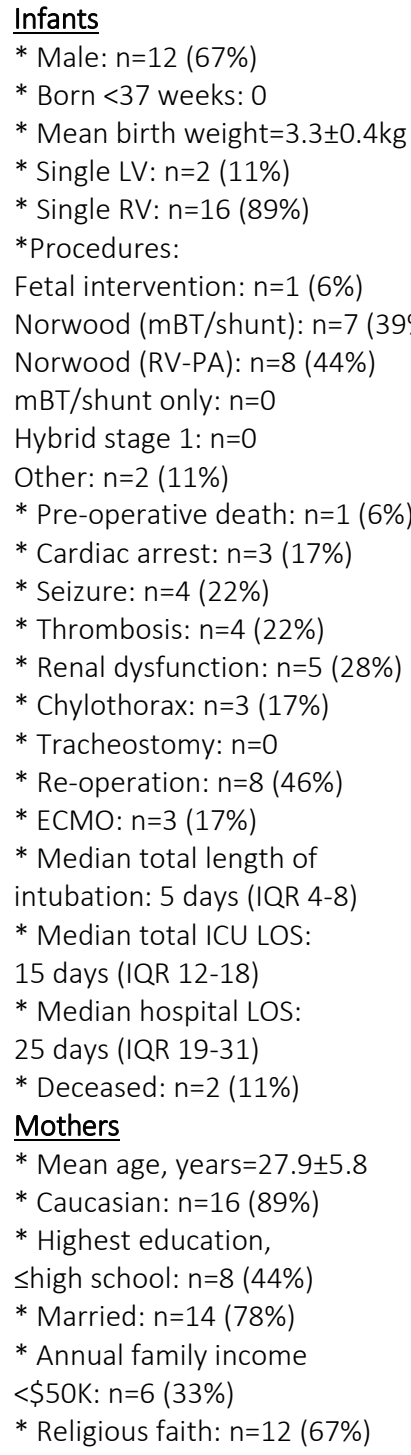 & 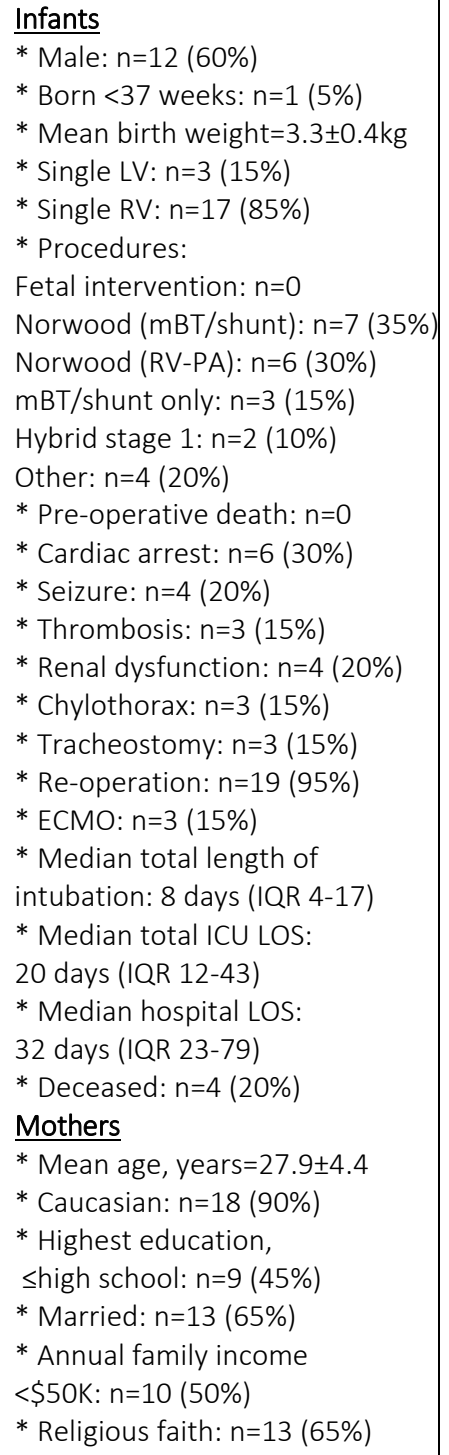 & $\mathrm{Nil}$ & $\begin{array}{c}\text { Usual care } \\
\text { (no or late } \\
\text { pediatric } \\
\text { palliative } \\
\text { care } \\
\text { consultation) }\end{array}$ & $\begin{array}{c}\text { Eligible } \\
\text { mothers } \\
\text { approached } \\
\text { at follow-up } \\
\text { fetal cardiac } \\
\text { visit, invited } \\
\text { to complete } \\
\text { web-based } \\
\text { survey. } \\
\text { Randomized } \\
\text { on admission } \\
\text { for neonatal } \\
\text { surgery to } \\
\text { INT or CON in } \\
\text { alternating } \\
\text { blocks. } \\
\text { INT received } \\
\text { early } \\
\text { pediatric } \\
\text { palliative care } \\
\text { consultation } \\
\text { before first } \\
\text { surgery. } \\
\text { Second } \\
\text { survey on } \\
\text { neonatal } \\
\text { discharge } \\
\text { (or } 30 \text { days } \\
\text { after first } \\
\text { surgery). }\end{array}$ \\
\hline
\end{tabular}




\begin{tabular}{|c|c|c|c|c|c|c|c|c|c|c|c|}
\hline $\begin{array}{c}\text { Uhm } \\
\text { et al. } 2019 \\
\text { Impact of } \\
\text { the mother- } \\
\text { nurse } \\
\text { partnership } \\
\text { programme } \\
\text { on mother } \\
\text { and } \\
\text { infant } \\
\text { outcomes in } \\
\text { pediatric } \\
\text { cardiac } \\
\text { intensive } \\
\text { care unit }\end{array}$ & $\begin{array}{l}\text { Seoul, } \\
\text { South } \\
\text { Korea } \\
\text { PICU }\end{array}$ & 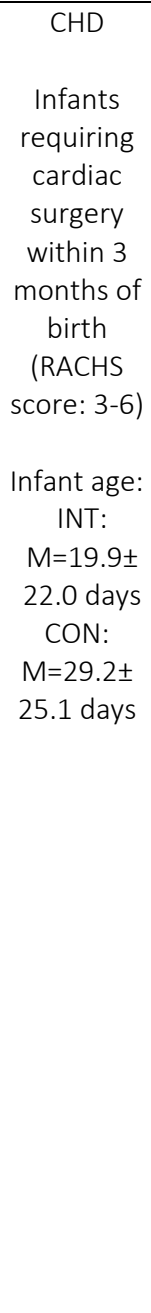 & $\begin{array}{c}\text { Non- } \\
\text { randomized } \\
\text { controlled } \\
\text { trial } \\
\text { Participants } \\
\text { 'consecutively } \\
\text { selected' } \\
\text { Registration: } \\
\text { NR }\end{array}$ & $\begin{array}{l}73 \text { mothers } \\
\text { Response } \\
\text { and attrition } \\
\text { rates not } \\
\text { reported }\end{array}$ & $n=36$ & $n=37$ & 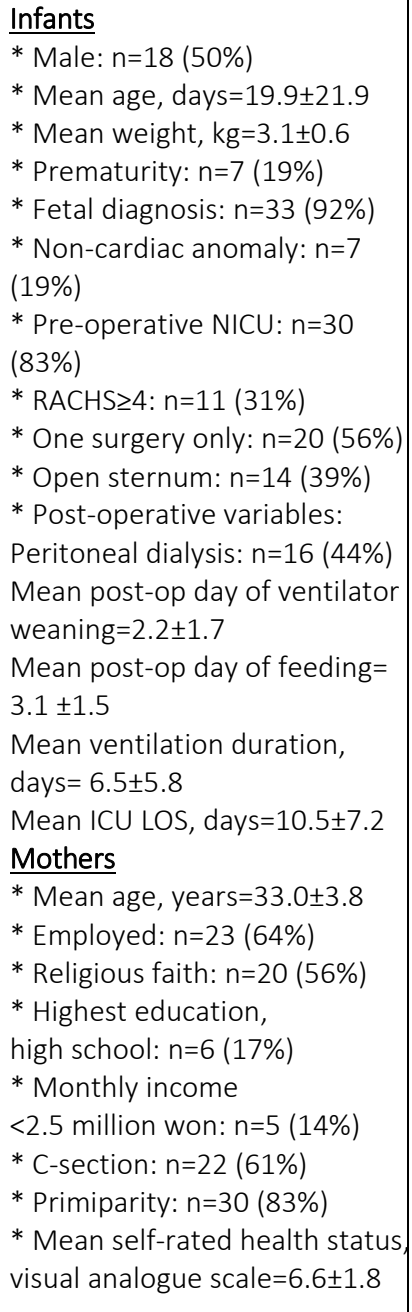 & 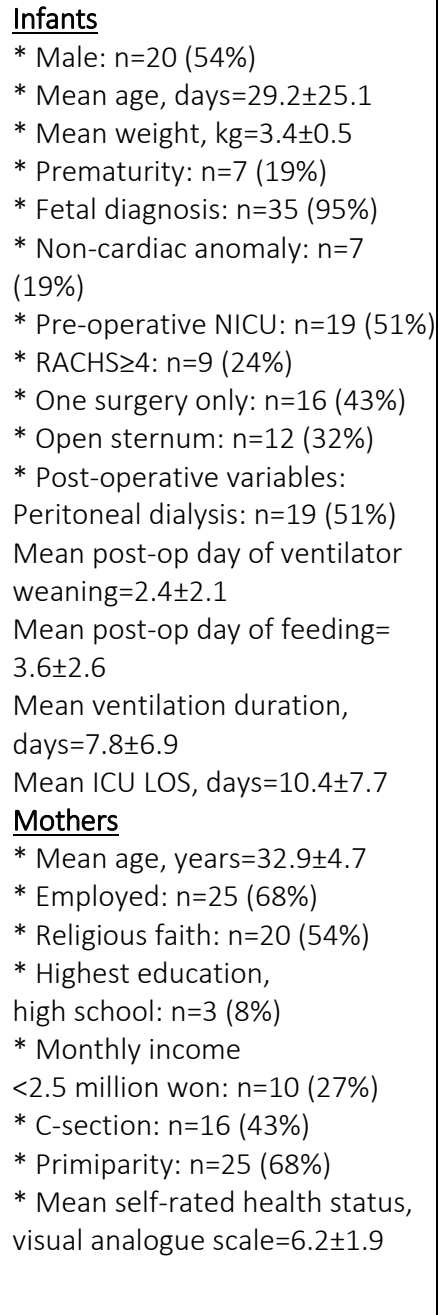 & $\begin{array}{l}\text { Greater } \\
\text { number of } \\
\text { infants } \\
\text { received } \\
\text { pre- } \\
\text { operative } \\
\text { NICU care in } \\
\text { INT vs. CON } \\
\text { group } \\
(p=0.006)\end{array}$ & $\begin{array}{l}\text { Usual care } \\
\text { and brief } \\
\text { brochure } \\
\text { with } \\
\text { guidance on } \\
\text { post-surgery } \\
\text { infant care. }\end{array}$ & $\begin{array}{l}\text { Pre- } \\
\text { intervention } \\
\text { data } \\
\text { collected } \\
\text { 18-36 hours } \\
\text { after PICU } \\
\text { admission via } \\
\text { self-report } \\
\text { survey. } \\
\text { Post- } \\
\text { intervention } \\
\text { survey data } \\
\text { collected } \\
12 \text { hours } \\
\text { before PICU } \\
\text { discharge. }\end{array}$ \\
\hline
\end{tabular}

Abbreviations: BDI: Beck Depression Inventory, CHD: congenital heart disease, CON: control group, ECMO: Extracorporeal membrane oxygenation, EPDS: Edinburgh

Postnatal Depression Scale, INT: intervention group, IQR: interquartile range, ISRA: Inventory of Situations and Responses of Anxiety, LOS: length of stay, LV: left ventricle, mBT: modified Blalock-Taussig shunt, NICU: neonatal intensive care unit, NR: not reported, PICU: pediatric intensive care unit, PSS-NICU: Parental Stressor Scale (NICU version), RACHS: Risk Adjustment for Congenital Heart Surgery, RV: right ventricle, RV-PA: right ventricle to pulmonary artery conduit. 
Table 2. Features of the five captured mental health interventions.

\begin{tabular}{|c|c|c|c|c|c|c|c|c|c|c|c|c|c|c|c|c|c|}
\hline \multirow[b]{2}{*}{ Trial } & \multirow[b]{2}{*}{$\begin{array}{l}\text { Intervention } \\
\text { Aims }\end{array}$} & \multirow{2}{*}{$\begin{array}{l}\text { Theoretical } \\
\text { Orientation } \\
\text { and } \\
\text { Therapeutic } \\
\text { Approach }\end{array}$} & \multirow[b]{2}{*}{ Interventionist } & \multirow[b]{2}{*}{ Timing } & \multirow[b]{2}{*}{ Dose } & \multirow{2}{*}{$\begin{array}{l}\text { Manual } \\
\text { and } \\
\text { Fidelity } \\
\text { Checks }\end{array}$} & \multicolumn{11}{|c|}{ Intervention Components } \\
\hline & & & & & & & $\begin{array}{c}\text { Medical } \\
\text { information }\end{array}$ & $\begin{array}{c}\text { Supported } \\
\text { exposure } \\
\text { to ICU }\end{array}$ & $\begin{array}{l}\text { Psycho- } \\
\text { education }\end{array}$ & $\begin{array}{c}\text { Goal setting } \\
\& \text { decision- } \\
\text { making }\end{array}$ & $\begin{array}{c}\text { Emotion } \\
\text { expression }\end{array}$ & \begin{tabular}{|c|} 
Active \\
coping \\
skills \\
training \\
\end{tabular} & $\begin{array}{c}\text { Attachment } \\
\text { or parenting } \\
\text { skills } \\
\text { training } \\
\end{array}$ & $\begin{array}{c}\text { Narrative } \\
\text { therapy }\end{array}$ & $\begin{array}{c}\text { Other } \\
\text { parents' } \\
\text { experiences }\end{array}$ & $\begin{array}{l}\text { Referral } \\
\text { to other } \\
\text { services }\end{array}$ & $\begin{array}{l}\text { Mind- } \\
\text { fulness }\end{array}$ \\
\hline $\begin{array}{l}\text { McCusker } \\
\text { et al. } 2010\end{array}$ & $\begin{array}{l}\text { To support parents } \\
\text { in processing } \\
\text { grief, promoting } \\
\text { effective mother- } \\
\text { infant interactions, } \\
\text { and teaching } \\
\text { active coping } \\
\text { strategies }\end{array}$ & $\begin{array}{c}\text { Transactional } \\
\text { model of stress } \\
\text { and coping, } \\
\text { using narrative } \\
\text { and problem- } \\
\text { solving therapy } \\
\text { processes }\end{array}$ & $\begin{array}{c}\text { Pediatric } \\
\text { clinical } \\
\text { psychologist } \\
\text { \& cardiac } \\
\text { nurse } \\
\text { specialist }\end{array}$ & $\begin{array}{l}\text { Within } \\
2 \text { weeks } \\
\text { of infant } \\
\text { hospital } \\
\text { admission }\end{array}$ & $\begin{array}{c}6 x \\
1-2 \text { hour } \\
\text { sessions } \\
\text { (average: } \\
8 \text { hours) }\end{array}$ & Yes & $\checkmark$ & $\checkmark$ & $\checkmark$ & $\checkmark$ & $\checkmark$ & $\checkmark$ & $\checkmark$ & $\checkmark$ & $\checkmark$ & & \\
\hline $\begin{array}{c}\text { Cano- } \\
\text { Giménez } \\
\text { et al. } 2015\end{array}$ & $\begin{array}{l}\text { To reduce anxiety } \\
\text { and depression in } \\
\text { parents of infants } \\
\text { in NICU }\end{array}$ & \begin{tabular}{|c|} 
Intervention \\
principles for \\
parents of \\
preterm \\
infants in NICU \\
\end{tabular} & Psychologist & $\begin{array}{l}\text { After } 3 \text { days } \\
\text { of infant NICU } \\
\text { admission }\end{array}$ & $\begin{array}{c}\text { NR; } \\
\text { implemented } \\
\text { in daily } \\
\text { practice }\end{array}$ & No & $\checkmark$ & $\checkmark$ & $\checkmark$ & & $\checkmark$ & & $\checkmark$ & & & & \\
\hline $\begin{array}{c}\text { Jabraili } \\
\text { et al. } 2017\end{array}$ & $\begin{array}{c}\text { To determine } \\
\text { effectiveness of a } \\
\text { support program } \\
\text { targeting mother- } \\
\text { infant attachment } \\
\text { in NICU }\end{array}$ & $\begin{array}{l}\text { Attachment } \\
\text { theory } \\
\text { principles }\end{array}$ & $\begin{array}{c}\text { Clinical } \\
\text { psychologist } \\
\text { (first 2 } \\
\text { sessions only) } \\
\text { \& research } \\
\text { team member }\end{array}$ & $\begin{array}{c}2 \text { sessions on } \\
2^{\text {nd }} \& 4^{\text {th }} \text { day } \\
\text { of admission, } \\
2 \text { sessions on } \\
2 \text { consecutive } \\
\text { days after } \\
\text { surgery }\end{array}$ & $\begin{array}{c}4 \times 45-\text { min } \\
\text { sessions }\end{array}$ & Unclear & $\checkmark$ & & $\checkmark$ & & $\checkmark$ & $\checkmark$ & $\checkmark$ & & & & \\
\hline $\begin{array}{l}\text { Hancock } \\
\text { et al. } 2018\end{array}$ & $\begin{array}{l}\text { To assess benefit } \\
\text { of early pediatric } \\
\text { palliative care } \\
\text { consultation on } \\
\text { stress in mothers } \\
\text { of neonates with } \\
\text { single ventricle } \\
\text { CHD }\end{array}$ & $\begin{array}{c}\text { Early pediatric } \\
\text { palliative } \\
\text { (comfort- } \\
\text { focused) } \\
\text { care }\end{array}$ & $\begin{array}{c}\text { Pediatric } \\
\text { palliative } \\
\text { care team } \\
\text { (physician, } \\
\text { nurse, nurse } \\
\text { practitioner, } \\
\text { social worker) }\end{array}$ & $\begin{array}{l}\text { On neonatal } \\
\text { admission, } \\
\text { before } \\
\text { first-stage } \\
\text { surgery }\end{array}$ & $\begin{array}{c}2 \text { to } 8 \\
\text { contacts } \\
\text { (median: } \\
3 \text { contacts) }\end{array}$ & Unclear & $\checkmark$ & & & $\checkmark$ & $\checkmark$ & & & & & $\checkmark$ & \\
\hline $\begin{array}{l}\text { Uhm } \\
\text { et al. } 2019\end{array}$ & $\begin{array}{l}\text { To assess impact } \\
\text { of mother-nurse } \\
\text { partnership } \\
\text { program on } \\
\text { maternal anxiety, } \\
\text { self-efficacy and } \\
\text { satisfaction with } \\
\text { PICU care }\end{array}$ & $\begin{array}{l}\text { Family- } \\
\text { centered } \\
\text { nursing } \\
\text { care }\end{array}$ & PICU nurse & $\begin{array}{l}24-48 \\
\text { hours post- } \\
\text { operative } \\
\text { PICU } \\
\text { admission }\end{array}$ & $\begin{array}{c}2 x \\
\text { 30-minutes } \\
\text { daily }\end{array}$ & Unclear & $\checkmark$ & & & $\checkmark$ & & & $\checkmark$ & & & & \\
\hline
\end{tabular}


Table 3. Risk of bias in randomized controlled trials $(n=2)$, rated using the Cochrane Collaboration Tool for Assessing Risk of Bias. ${ }^{71}$

For each domain, studies were rated as having a high (-), low (+), or unclear(?) risk of bias.

\begin{tabular}{|c|c|c|c|c|c|c|c|}
\hline & $\begin{array}{c}\text { Randomization } \\
\text { (selection bias) }\end{array}$ & $\begin{array}{c}\text { Allocation } \\
\text { concealment } \\
\text { (selection bias) }\end{array}$ & $\begin{array}{l}\text { Double blinding } \\
\text { (performance bias) }\end{array}$ & $\begin{array}{c}\text { Blinding } \\
\text { of outcome } \\
\text { (detection bias) }\end{array}$ & $\begin{array}{c}\text { Incomplete } \\
\text { outcome data } \\
\text { (attrition bias) }\end{array}$ & \begin{tabular}{|c|} 
Selective \\
reporting \\
(reporting bias)
\end{tabular} & Other bias? \\
\hline Hancock et al. 2018 & - & - & - & - & + & $?$ & + \\
\hline Jabraili et al. 2017 & + & $?$ & - & - & ? & - & - \\
\hline
\end{tabular}


Table 4. Risk of bias in non-randomized controlled trials $(n=3)$, rated using the Risk of Bias in Non-Randomized Studies of Interventions $\left(\right.$ ROBINS-I) tool. ${ }^{72}$

For each domain, studies were rated as having a low (L), moderate $(M)$, serious $(S)$, critical $(C)$, or unclear (?) risk of bias.

\begin{tabular}{|c|c|c|c|c|c|c|c|c|c|}
\hline & Confounding & $\begin{array}{l}\text { Participant } \\
\text { selection }\end{array}$ & $\begin{array}{c}\text { Classification } \\
\text { of interventions }\end{array}$ & $\begin{array}{c}\text { Deviation } \\
\text { from intended } \\
\text { interventions }\end{array}$ & $\begin{array}{c}\text { Missing } \\
\text { data }\end{array}$ & $\begin{array}{c}\text { Measurement } \\
\text { of outcomes }\end{array}$ & $\begin{array}{c}\text { Selection } \\
\text { of reported } \\
\text { results }\end{array}$ & $\begin{array}{c}\text { Overall } \\
\text { rating }\end{array}$ & $\begin{array}{c}\text { Implementation } \\
\text { integrity }\end{array}$ \\
\hline McCusker et al., 2009 & $\mathbf{M}$ & $\mathbf{S}$ & $\mathbf{L}$ & $?$ & $\mathbf{S}$ & $\mathbf{S}$ & $\mathbf{M}$ & $\mathbf{S}$ & $\mathbf{L}$ \\
\hline Cano- Giménez et al., 2015 & $\mathbf{S}$ & $\mathbf{S}$ & $\mathbf{S}$ & $?$ & $?$ & $\mathbf{S}$ & C & $\mathrm{C}$ & $?$ \\
\hline Uhm et al., 2018 & $\mathbf{M}$ & $?$ & $\mathbf{S}$ & $?$ & $?$ & $\mathbf{S}$ & $\mathbf{M}$ & $\mathbf{S}$ & $?$ \\
\hline
\end{tabular}


Table 5. Quality of evidence, rated using the Grading of Recommendations Assessment, Development and Evaluation (GRADE) tool. ${ }^{73}$

\begin{tabular}{|c|c|c|c|c|c|c|c|}
\hline Outcome & $\begin{array}{c}\text { Number } \\
\text { of studies }\end{array}$ & $\begin{array}{c}\text { Limitations in } \\
\text { study design and } \\
\text { implementation }\end{array}$ & $\begin{array}{c}\text { Unexplained } \\
\text { heterogeneity or } \\
\text { inconsistency of } \\
\text { results }\end{array}$ & $\begin{array}{c}\text { Indirectness } \\
\text { of evidence }\end{array}$ & $\begin{array}{c}\text { Imprecision } \\
\text { of results }\end{array}$ & $\begin{array}{c}\text { High probability } \\
\text { of publication } \\
\text { bias }\end{array}$ & $\begin{array}{c}\text { Overall } \\
\text { quality } \\
\text { of evidence* }\end{array}$ \\
\hline Anxiety & 4 & Very Serious & No problem & No problem & Very Serious & Serious & Very low +--- \\
\hline
\end{tabular}

*High quality=further research is very unlikely to change our confidence in the estimate of effect; moderate quality=further research is likely to have an important impact on our confidence in the estimate of effect and may change the estimate, low quality=further research is very likely to have an important impact on our confidence in the estimate of effect and is likely to change the estimate, very low quality=we are very uncertain about the estimate. 
Table 6. Key findings and limitations of the five captured trials.

\begin{tabular}{|c|c|c|c|c|c|c|c|}
\hline Trial & Trial Design & $\begin{array}{l}\text { Primary } \\
\text { Outcome }\end{array}$ & Other Outcomes & $\begin{array}{c}\text { Longest } \\
\text { Follow-Up }\end{array}$ & Main Results & Sufficient Power? & Key Limitations \\
\hline $\begin{array}{l}\text { McCusker } \\
\text { et al. } 2010\end{array}$ & $\begin{array}{c}\text { Non- } \\
\text { randomized } \\
\text { controlled } \\
\text { trial }\end{array}$ & $\begin{array}{l}\text { Infant } \\
\text { neuro- } \\
\text { development } \\
\text { Assessed } \\
\text { at baseline \& } \\
\text { 6-months } \\
\text { using Bayley } \\
\text { Scales of } \\
\text { Infant } \\
\text { Development } \\
\text { (BSID-II) }\end{array}$ & $\begin{array}{l}\text { Maternal anxiety (baseline \& } \\
6 \text {-months): State-Trait Anxiety } \\
\text { Inventory (STAI-State). } \\
\text { Maternal worry (baseline \& } \\
6 \text {-months): Worry Scale } \\
\text { (severity of worry in context of } \\
\text { child with chronic illness). } \\
\text { Maternal coping (baseline \& 6- } \\
\text { months): active coping, } \\
\text { planning, positive } \\
\text { reinterpretation, and } \\
\text { behavioural disengagement, } \\
\text { using the situational } \\
\text { multidimensional coping } \\
\text { inventory (COPE) subscales. } \\
\text { Infant feeding (6-months): } \\
\text { mins spent on last feed, self- } \\
\text { reported difficulty introducing } \\
\text { solids, and numbers } \\
\text { breastfeeding in each group. }\end{array}$ & 6 months & $\begin{array}{l}\text { - Infant mental development scores significantly higher (better) } \\
\text { for intervention than control group at } 6 \text {-months post- } \\
\text { intervention, irrespective of syndromal status ( } p=0.02 \text { ). } \\
\text { - More mothers in control group found introduction to solids } \\
\text { 'quite' or 'very difficult' compared to mothers in intervention } \\
\text { group ( } p=0.03 \text { ). } \\
\text { - After controlling for baseline STAl-State scores, mothers in } \\
\text { intervention group reported lower anxiety than mothers in } \\
\text { control group at 6-months ( } p=0.04 \text { ). } \\
\text { - Mothers in intervention group reported lower worry than } \\
\text { mothers in control group at } 6 \text {-months ( } p=0.04 \text { ). } \\
\text { - Mothers in intervention group reported greater use of positive } \\
\text { reinterpretation than mothers in control group ( } p=0.04 \text { ). } \\
\text { - No difference in infant psychomotor scores between } \\
\text { intervention and control groups at } 6 \text {-months (both groups } \\
\text { scored } 1-2 \text { SD below normative mean, suggesting clinically- } \\
\text { significant delay). } \\
\text { - No difference in time taken to complete last feed between } \\
\text { intervention and control groups. } \\
\text { - No mothers in control group breastfeeding at 6-months } \\
\text { compared to 6/31 mothers in intervention group ( } p=0.03 \text { ). } \\
\text { - No differences found for other maternal coping strategies. }\end{array}$ & $\begin{array}{c}\text { Yes. } \\
\text { Sample size } \\
\text { based on } 0.75 \\
\text { standardized } \\
\text { mean difference } \\
\text { between groups, } \\
\text { as indicative of } \\
\text { clinical relevance } \\
\text { on Bayley Scales. } \\
\text { Sample size of } 46 \\
\text { families required } \\
\text { for power of } 0.8 \\
(p<0.05) .\end{array}$ & $\begin{array}{l}\text { - } \text { Non-randomized group allocation } \\
\text { and differential attrition rate, } \\
\text { raising concerns about potential } \\
\text { bias between groups. } \\
\text { - Intervention delivered to all } \\
\text { participants by same two } \\
\text { clinicians, yielding potential bias. } \\
\text { - Bayley tester not blind to group } \\
\text { allocation. } \\
\text { - Integrated suite of interventions } \\
\text { makes it difficult to discern which } \\
\text { components may have been most } \\
\text { efficacious. } \\
\text { - Fathers' involvement unclear. } \\
\text { - Longer follow-up desirable to } \\
\text { determine whether gains were } \\
\text { maintained. }\end{array}$ \\
\hline $\begin{array}{c}\text { Cano- } \\
\text { Giménez } \\
\text { et al. } 2015\end{array}$ & $\begin{array}{c}\text { Non- } \\
\text { randomized } \\
\text { controlled } \\
\text { trial }\end{array}$ & NR & $\begin{array}{l}\text { Stress (at day 3): Parental } \\
\text { Stressor Scale (PSS-NICU). } \\
\text { Anxiety (at day 15): Inventory } \\
\text { of Situations and Responses of } \\
\text { Anxiety (ISRA). } \\
\text { Depression (on day of NICU } \\
\text { discharge): Beck Depression } \\
\text { Inventory (BDI) and Edinburgh } \\
\text { Postnatal Depression Scale } \\
\text { (EPDS). }\end{array}$ & \begin{tabular}{c|} 
Day of \\
NICU \\
discharge
\end{tabular} & $\begin{array}{l}\text { - On day } 15, \text { no mothers or fathers in intervention group } \\
\text { reported anxiety, compared to } 97.5 \% \text { of mothers and } 89.7 \% \text { of } \\
\text { fathers in control group ( } p=0.001 \text { ). } \\
\text { - On day of discharge, } 50 \% \text { mothers and } 20 \% \text { fathers in } \\
\text { intervention group reported depressive symptoms in 'clinical' } \\
\text { range on BDI, compared to } 100 \% \text { of parents in control group } \\
\text { ( } p<0.001 \text { ). } \\
\text { - On day of discharge, 'probable depression' (on EPDS) reported } \\
\text { by } 37.5 \% \text { of mothers and } 24 \% \text { of fathers in intervention group } \\
\text { compared to } 100 \% \text { of mothers and } 89.7 \% \text { of fathers in control } \\
\text { group. }\end{array}$ & NR & $\begin{array}{l}\text { - Number and duration of sessions } \\
\text { not reported. } \\
\text { - Small sample size, especially for } \\
\text { fathers, and reasons for attrition } \\
\text { not reported. } \\
\text { - Response rate not calculated and } \\
\text { no data on decliners provided. } \\
\text { - Sample included mixed diagnostic } \\
\text { groups, with no analysis of } \\
\text { potential differences in outcomes } \\
\text { according to diagnosis. } \\
\text { - Changes in outcomes over time } \\
\text { not assessed. }\end{array}$ \\
\hline $\begin{array}{c}\text { Jabraili } \\
\text { et al. } 2017\end{array}$ & $\begin{array}{c}\text { Randomized } \\
\text { controlled } \\
\text { trial }\end{array}$ & $\begin{array}{c}\text { Mother-infant } \\
\text { attachment }\end{array}$ & NR & $\begin{array}{l}\text { Day of } \\
\text { last INT } \\
\text { session }\end{array}$ & $\begin{array}{l}\text { - Mothers in intervention group reported higher mother-infant } \\
\text { attachment scores post-intervention, compared to baseline } \\
(p<0.01) \text {. }\end{array}$ & Unclear & $\begin{array}{l}\text { - Mother-infant attachment } \\
\text { measured using self-report rather }\end{array}$ \\
\hline
\end{tabular}




\begin{tabular}{|c|c|c|c|c|c|c|c|}
\hline & & $\begin{array}{l}\text { Assessed at } \\
\text { baseline \& } \\
\text { after } \\
\text { intervention } \\
\text { completion } \\
\text { using the } \\
\text { self-report } \\
\text { Maternal } \\
\text { Attachment } \\
\text { Inventory. }\end{array}$ & & $\begin{array}{c}\text { (after } \\
\text { infant's } \\
\text { surgery) }\end{array}$ & $\begin{array}{l}\text { - No difference in mother-infant attachment scores from } \\
\text { baseline to follow-up for mothers in control group ( } p>0.05) \text {. } \\
\text { - Change in mother-infant attachment scores from baseline to } \\
\text { follow-up were greater in the intervention vs control group } \\
(p=0.01) \text {. }\end{array}$ & & $\begin{array}{l}\text { than more direct, observational } \\
\text { techniques. } \\
\text { - No data on decliners reported. } \\
\text { - No data on maternal perinatal or } \\
\text { infant medical factors reported. } \\
\text { - Intervention delivered to all } \\
\text { participants by the same two } \\
\text { interventionalists (including a } \\
\text { member of the research team), } \\
\text { introducing potential bias. } \\
\text { - Integrated suite of interventions } \\
\text { makes it difficult to discern which } \\
\text { components may have been most } \\
\text { efficacious. } \\
\text { - Short-term follow-up only. } \\
\text { - No information on usual care } \\
\text { received by control group. } \\
\text { - Small sample size. } \\
\text { - Fathers not included. } \\
\text { - Potential impact on infant } \\
\text { outcomes not examined. } \\
\text { - Potential role of other maternal } \\
\text { psychosocial factors not examinec } \\
\text { (e.g., anxiety, coping skills). }\end{array}$ \\
\hline $\begin{array}{c}\text { Hancock } \\
\text { et al. } 2018\end{array}$ & $\begin{array}{c}\text { Pilot } \\
\text { randomized } \\
\text { controlled } \\
\text { trial }\end{array}$ & $\begin{array}{l}\text { Overall } \\
\text { maternal } \\
\text { stress } \\
\text { Combined } \\
\text { anxiety, } \\
\text { depression, } \\
\text { coping, quality } \\
\text { of life and } \\
\text { family } \\
\text { functioning } \\
\text { scores. }\end{array}$ & $\begin{array}{l}\text { Depression: Beck Depression } \\
\text { Inventory-II (BDI). } \\
\text { Anxiety: State-Trait Anxiety } \\
\text { Inventory (STAI). } \\
\text { Coping: Brief COPE (adaptive } \\
\text { \& problematic coping). } \\
\text { Maternal health-related } \\
\text { quality of life: PedsQL Family } \\
\text { Impact Module (maternal } \\
\text { functioning subscales) } \\
\text { Perceived family functioning: } \\
\text { PedsQL Family Impact Module } \\
\text { (family functioning subscales). }\end{array}$ & $\begin{array}{l}30 \text { days } \\
\text { after } \\
\text { infant } \\
\text { birth }\end{array}$ & $\begin{array}{l}\text { - During intervention, } 89 \% \text { of intervention group had 'good' to } \\
\text { 'excellent' understanding of their baby's diagnosis. } \\
\text { - Most common maternal concerns: fears of medical instability } \\
\text { and infant suffering, surgical complications, poor } \\
\text { neurodevelopmental outcome, and death. } \\
\text { - } 61 \% \text { reported additional life stressors relating to work, } \\
\text { finances, family and physical health concerns. } \\
\text { - Post-intervention, significant reduction in maternal anxiety } \\
\text { scores (from antenatal to postnatal assessment) for } \\
\text { intervention compared with control group (7.6-point } \\
\text { reduction for intervention group vs 0.3-point reduction for } \\
\text { control group, } p=0.02 \text { ). } \\
\text { - Intervention group reported greater positive reframing } \\
\text { compared with control group ( } p=0.03 \text { ), and a trend for higher } \\
\text { adaptive coping ( } p=0.06) \text {. } \\
\text { - Intervention group reported 11.3-point increase in } \\
\text { communication scores compared with 1-point increase in } \\
\text { control group (not statistically significant). }\end{array}$ & $\begin{array}{c}\text { No, } \\
\text { if based on } \\
\text { conventional } \\
80 \% \text { power. } \\
\\
\text { Sample size of } 38 \\
\text { (19 participants } \\
\text { per group) would } \\
\text { achieve } 77 \% \\
\text { power to detect } \\
\text { a } 25 \% \text { mean } \\
\text { difference in } \\
\text { total distress } \\
\text { scores between } \\
\text { groups }(p<0.05) .\end{array}$ & $\begin{array}{l}\text { - Inpatient unit nurses and } \\
\text { physicians not blinded to group } \\
\text { randomization. } \\
\text { - Limited generalizability due to } \\
\text { setting (single tertiary care } \\
\text { centre), sample (single ventricle } \\
\text { CHD only), and participant } \\
\text { demographics (predominantly } \\
\text { Caucasian). } \\
\text { - Small sample size. } \\
\text { - Incomplete data on eligible non- } \\
\text { participants. } \\
\text { - High variation in intervention } \\
\text { content and delivery makes it } \\
\text { difficult to identify 'active } \\
\text { ingredients' of intervention. } \\
\text { - Fathers not included. } \\
\text { - Potential impact of intervention } \\
\text { on infant outcomes not } \\
\text { examined. }\end{array}$ \\
\hline
\end{tabular}




\begin{tabular}{|c|c|c|c|c|c|c|c|}
\hline & & & $\begin{array}{l}\text { All outcomes assessed during } \\
\text { pregnancy and } 30 \text { days } \\
\text { postpartum. }\end{array}$ & & $\begin{array}{l}\text { - Intervention group reported 5-point increase in family } \\
\text { relationships scores compared with 2.6-point reduction in } \\
\text { control group (not statistically significant). } \\
\text { - No significant difference in change in overall 'maternal stress' } \\
\text { (primary outcome), depression or HRQOL scores between } \\
\text { groups reported. }\end{array}$ & & \\
\hline $\begin{array}{c}\text { Uhm } \\
\text { et al. } 2019\end{array}$ & $\begin{array}{c}\text { Non- } \\
\text { randomized } \\
\text { controlled } \\
\text { trial }\end{array}$ & $\begin{array}{c}\text { Maternal } \\
\text { satisfaction with } \\
\text { clinical care } \\
\text { Assessed 18-36 } \\
\text { hours of PICU } \\
\text { admission and } \\
\text { 12-hours before } \\
\text { PICU discharge, } \\
\text { using PICU } \\
\text { Parental } \\
\text { Satisfaction } \\
\text { Scale short-form } \\
\text { (PICU-PSS-SF); } \\
5 \text { subscales: } \\
\text { information, } \\
\text { care and cure, } \\
\text { organisation, } \\
\text { parent } \\
\text { participation, } \\
\text { professional } \\
\text { attitude. }\end{array}$ & $\begin{array}{l}\text { Parenting confidence } \\
\text { (18-36 hrs after admission \& } \\
12 \text { hrs before discharge): } \\
\text { Karitane Parenting Confidence } \\
\text { Scale ( } 3 \text { subscales: parenting, } \\
\text { support, development). } \\
\text { Mother-nurse partnership } \\
\text { (18-36 hrs after admission \& } \\
12 \text { hrs before discharge): } \\
\text { Perceived Parent-Nurse } \\
\text { Partnership Scale (PPNPS; } \\
7 \text { subscales: reciprocity, } \\
\text { professional knowledge, } \\
\text { sensitivity, collaboration, } \\
\text { communication, shared } \\
\text { information, cautiousness). } \\
\\
\text { Maternal anxiety (18-36 hrs } \\
\text { after admission \& } 12 \text { hrs before } \\
\text { discharge): State-Trait Anxiety } \\
\text { Inventory (STAl-State). } \\
\text { Infant feeding (12 hrs before } \\
\text { discharge): Time taken to reach } \\
\text { full oral feeding. } \\
\text { Length of post-operative } \\
\text { hospital stay: chart review. }\end{array}$ & $\begin{array}{c}30 \text { days } \\
\text { after } \\
\text { infant } \\
\text { birth }\end{array}$ & $\begin{array}{l}\text { - Mothers in intervention group reported greater improvement } \\
\text { in parental satisfaction than control group }(p<0.001) \text {. } \\
\text { Improvements found for all subscales. } \\
\text { - Mothers in intervention group reported greater improvement } \\
\text { in self-efficacy compared to control group ( } p=0.008) \text {. } \\
7 \text { mothers in control group scored in clinical range post-trial, } \\
\text { compared to } 0 \text { mothers in intervention group. } \\
\text { - Mothers in intervention group reported greater improvement } \\
\text { in perceived nurse partnership than mothers in control group } \\
\text { ( } p<0.001) \text {. Improvements found for all subscales. } \\
\text { - Mothers in intervention group reported lower anxiety than } \\
\text { mothers in control group ( } p<0.001) \text {. } \\
\text { - No differences between groups in time taken for infant to reach } \\
\text { full oral feeding or length of PICU stay. }\end{array}$ & $\begin{array}{c}\text { Yes. } \\
\text { Assuming effect } \\
\text { size of } 0.60 \\
\text { (McCusker et al., } \\
2010) \text { and power } \\
\text { of } 0.80, \text { sample } \\
\text { size of } 36 \\
\text { mothers per } \\
\text { group required } \\
(p<0.05) .\end{array}$ & $\begin{array}{l}\text { - Single site study and unique } \\
\text { environment (i.e. PICU with } \\
\text { extremely restrictive visiting } \\
\text { policy). } \\
\text { - Non-randomized and lack of } \\
\text { information regarding recruitment, } \\
\text { enrolment and group assignment. } \\
\text { - Fathers not included. } \\
\text { - Response and attrition rates not } \\
\text { reported. } \\
\text { - Lack of detailed description of } \\
\text { intervention components, limiting } \\
\text { opportunity for replication. }\end{array}$ \\
\hline
\end{tabular}


Table 7. Summary of intervention outcomes based on effect sizes (Hedge's $g$ ).

\begin{tabular}{|c|c|c|c|c|c|c|c|c|c|c|c|}
\hline Trial & Anxiety & Depression & Worry & Coping & Parenting & $\begin{array}{l}\text { Quality } \\
\text { of Life }\end{array}$ & $\begin{array}{l}\text { Infant } \\
\text { Feeding }\end{array}$ & $\begin{array}{c}\text { Infant } \\
\text { Neurodevelopment }\end{array}$ & $\begin{array}{l}\text { Physical } \\
\text { Health }\end{array}$ & $\begin{array}{c}\text { Family } \\
\text { Functioning }\end{array}$ & $\begin{array}{c}\text { Communication } \\
\text { and Satisfaction } \\
\text { with Care } \\
\end{array}$ \\
\hline $\begin{array}{l}\text { McCusker } \\
\text { et al. } 2010\end{array}$ & $0.58 \uparrow$ & - & $0.40 \uparrow$ & $\begin{array}{c}\text { Active coping: } \\
0.62 \varnothing \\
\text { Planning: } \\
0.48 \varnothing \\
\text { Positive re- } \\
\text { interpretation: } \\
0.66 \uparrow \\
\text { Behavioral } \\
\text { disengagement: } \\
0.27 \varnothing \\
\end{array}$ & - & - & $\begin{array}{l}\text { Means and } \\
\text { SDs not } \\
\text { reported }\end{array}$ & $\begin{array}{c}\text { Mental development: } \\
0.81 \uparrow \\
\text { Psychomotor development: } \\
-0.13 \varnothing \\
\\
\text { If infants with } \\
\text { syndrome excluded } \\
\text { Mental: } 0.66 \uparrow \\
\text { Psychomotor: }-0.17 \varnothing\end{array}$ & - & - & (1) \\
\hline $\begin{array}{l}\text { Hancock } \\
\text { et al. } 2018\end{array}$ & $\begin{array}{l}\text { Means and } \\
\text { SDs not } \\
\text { reported }\end{array}$ & $0.28 \varnothing$ & $\begin{array}{c}\text { PedsQL Family } \\
\text { Impact Module } \\
\text { (Worry subscale): } \\
0.20 \varnothing \\
\text { Change in mean } \\
\text { PedsQL Family } \\
\text { Impact Module } \\
\text { (Worry subscale) } \\
\text { from prenatal to } \\
\text { postnatal period: } \\
0.28 \varnothing\end{array}$ & $\begin{array}{c}\text { Overall adaptive } \\
\text { coping: } \\
0.27 \varnothing \\
\text { Active coping: } \\
0.18 \varnothing \\
\text { Positive } \\
\text { reframing: } \\
0.61 \uparrow \\
\text { Overall } \\
\text { problematic } \\
\text { coping: } \\
0.20 \varnothing\end{array}$ & 1 & $\begin{array}{c}\text { Maternal health- } \\
\text { related quality of } \\
\text { life (HRQOL): } \\
-0.16 \varnothing \\
\text { Change in mean } \\
\text { maternal } \\
\text { HRQOL scores } \\
\text { from prenatal to } \\
\text { postnatal period: } \\
0.14 \varnothing\end{array}$ & - & - & - & $\begin{array}{c}\text { Total family } \\
\text { impact: } 0.01 \emptyset \\
\text { Family } \\
\text { relationships: } \\
-0.19 \varnothing \\
\\
\text { Change in mean } \\
\text { scores from } \\
\text { prenatal to } \\
\text { postnatal period: } \\
\text { Total family } \\
\text { impact: } 0.30 \emptyset \\
\text { Family } \\
\text { relationships: } \\
0.43 \varnothing \\
\end{array}$ & $\begin{array}{c}\text { Communication: } \\
0.51 \varnothing \\
\text { Change in mean } \\
\text { communication } \\
\text { scores from } \\
\text { prenatal to } \\
\text { postnatal period: } \\
0.49 \varnothing\end{array}$ \\
\hline $\begin{array}{l}\text { Uhm \& } \\
\text { Kim } 2019\end{array}$ & $0.79 \uparrow$ & - & - & - & $\begin{array}{c}\text { Overall self- } \\
\text { efficacy: } \\
0.94 \uparrow \\
\text { Parenting: } 0.98 \uparrow \\
\text { Support: } 0.84 \varnothing \\
\text { Development: } \\
0.40 \varnothing\end{array}$ & 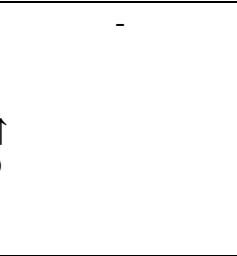 & $\begin{array}{c}\text { Time to } \\
\text { reach full } \\
\text { oral feeds: } \\
0.24 \varnothing\end{array}$ & - & $\begin{array}{l}\text { Infant post- } \\
\text { operative } \\
\text { stay: } 0.01 \emptyset\end{array}$ & - & $\begin{array}{c}\text { Overall } \\
\text { satisfaction with } \\
\text { care: } 1.15 \uparrow \\
\text { Perceived mother- } \\
\text { nurse partnership: } \\
1.20 \uparrow\end{array}$ \\
\hline
\end{tabular}

Ø: no effect, $\uparrow$ : favors intervention, $\downarrow$ : favors control, where $p<0.05$ was considered statistically significant. Cano-Giménez et al. 2015 did not report means or standard deviations (SD), and means and SDs reported in Jabraili et al., 2017 were unclear, thus, neither study is included in this table. 